\title{
PRÁTICAS DE TRABALHO DA CULTURA POPULAR NO AGRESTE DE PERNAMBUCO: entre o moderno e o tradicional
}

1- Elisabeth Cavalcante dos Santos*

Doutora em Administração pela Universidade Federal da Paraíba (PPGA/UFPB), Brasil. Professora da Universidade Federal de Pernambuco (CAA/UFPE), Brasil. elisabethcsantos@gmail.com http://lattes.cnpq.br/4908041021886939/

\section{2- Diogo Henrique Helal}

Doutor em Ciências Humanas pela Universidade Federal de Minas Gerais (UFMG), Brasil. Professor da Universidade Federal da Paraíba (PPGA/UFPB), Brasil. diogohh@yahoo.com.br http://lattes.cnpq.br/5268265898312612/

Diego Maganhotto Coraiola - Editor Geral
Editor responsável pela submissão:
Diego Maganhotto Coraiola.
Artigo analisado via processo de revisão duplo cego (Double-blind). Recebido em: 20/02/2017 Aprovado em: 28/07/2017 última Alteração: 16/08/2017 


\title{
PRÁTICAS DE TRABALHO DA CULTURA POPULAR NO AGRESTE DE PERNAMBUCO: ENTRE O MODERNO E O TRADICIONALRESUMO
}

\section{RESUMO}

Este artigo tem como pergunta de pesquisa "como os hibridismos entre ethos tradicionais e modernos estão presentes nas práticas de trabalho da cultura popular no Agreste pernambucano?" Neste sentido, lançamos como objetivo compreender o hibridismo tradicional-moderno nas práticas de trabalho da cultura popular no Agreste pernambucano e as respostas dadas a estes hibridismos, a partir do estudo de duas organizações culturais: uma banda de pífano e o grupo bumba-meu-boi. Para isso, foi proposta uma matriz de compreensão teórica que agrega a noção de prática dos Estudos Baseados em Prática e, mais especificamente, da etnometodologia, as noções weberianas de ethos e ação social, para a compreensão do que são práticas híbridas. Por meio da própria epistemologia dos Estudos Baseados em Práticas, do método etnometodológico e de abordagem qualitativa, realizamos e registramos entrevistas semiestruturadas, conversas informais e observações participantes. Através de análise de orientação etnometodológica, considerando como categorias analíticas a noção de prática, membro, linguagem e significados, identificamos sete práticas existentes no contexto de trabalho das organizações de cultura popular. Utilizando a matriz de interpretação proposta, que tem como categorias analíticas as noções de ethos e ação social, vários hibridismos foram identificados em cada prática. Observou-se que isso acontece principalmente em função de algumas práticas possuírem ethos cuja orientação é essencialmente tradicional, mas recursos financeiros se fazem necessários para a manutenção dessas práticas, resultando na necessidade de elaboração de projetos culturais, ofícios, leis etc., visando fins específicos. Respostas aos hibridismos foram observadas, dentre elas, a ação dos líderes de grupos de cultura popular, que caminham entre o ethos tradicional e o moderno, utilizando meios modernos para manutenção do tradicional, evidenciando a existência de uma interdependência entre estes elementos. Como principal contribuição da presente pesquisa, evidenciamos a abordagem multi e interdisciplinar proposta, a fim de compreender fenômenos complexos como o trabalho com cultura popular.

\section{Palavras-chave}

Práticas; Hibridismos; Moderno; Tradicional; Cultura popular; Agreste de Pernambuco.

\section{WORK PRACTICES OF POPULAR CULTURE IN THE AGRESTE OF PERNAMBUCO: BETWEEN THE MODERN AND THE TRADITIONAL}

\begin{abstract}
This article has as a research question the following: "how the hybridity between traditional and modern ethos are present in the work practices of the popular culture in the Agreste of Pernambuco?" In this sense, we aimed to understand the traditional-modern hybridism in the work practices of the popular culture in the Agreste of Pernambuco and the answers given to these hybridisms, from the study of two cultural organizations: a band of pífano and the bumba-meu-boi group. In order to achieve such, a theoretical understanding matrix was proposed, which adds the practice notion of Practical Based Studies, and more specifically, the ethnomethodology, to the Weberian notions of ethos and social action, in order to understand what hybrid practices are. Through the epistemology of Practical Based Studies, of ethnomethodological method, and a qualitative approach, we conducted and recorded semi-structured interviews, informal conversations, and participant observations. Through analysis of ethnomethodological orientation, considering as analytical categories the notion of practice, member, language and meanings, we identified seven existing practices in the work context of popular culture organizations. Using the proposed theoretical understanding matrix, which has as analytical categories the notions of ethos and social action, several hybridisms have been identified in each practice, mainly because some practices have ethos in whose orientation is essentially traditional, but financial resources are necessary for the maintenance of these practices, resulting in the need to elaborate cultural projects, official documents, laws, etc., for specific purposes. Responses to the hybridisms have been observed, among them, the action of the leaders of popular culture groups, who walk between the traditional and the modern ethos, using modern means to maintain the traditional, evidencing the existence of an interdependence between these elements. As the main contribution of the present research, we highlight the proposed multi and interdisciplinary approach in order to understand complex phenomena such as the work with popular culture.
\end{abstract}

\section{Keywords}

Practices; Hybridism; Modern; Traditional; Popular culture; Agreste of Pernambuco. 


\section{Introdução}

É cada vez mais evidente a necessidade de desenvolver conhecimento local, capaz de dialogar com a realidade vivida pelos agentes sociais. Mais precisamente em relação à realidade latinoamericana, autores como Alcadipani, Khan, Gantman e Nkomo (2012), Imas e Weston (2012) reforçam a importância do conhecimento produzido pelo Sul e no Sul; um conhecimento que se utiliza de uma epistemologia própria e que estuda as diversas realidades situadas no sul - também chamados de estudos subalternos por Rosa e Alcadipani (2013).

Neste espaço denominado "sul" está localizado um país de extremas contradições sociais, culturais e econômicas, nomeadamente, o Brasil (Souza, 2000). Neste país, e principalmente em regiões historicamente tidas como "atrasadas", como a região do Nordeste brasileiro e do Agreste pernambucano, existem dinâmicas singulares, que encerram em si coexistências e contradições (Albuquerque, 2011; Araújo, 2004; Sá, 2013, 2015; Véras de Oliveira, 2013) entre pressupostos modernos e tradicionais. Como bem pontua Véras de Oliveira (2013) sobre a região do Agreste pernambucano, nela se desenvolve uma dinâmica singular, na qual o alto crescimento econômico (decorrente principalmente do desenvolvimento da indústria têxtil da região) e o elemento informal, precário e marcado por estruturas de poder arcaicas, coexistem (Véras de Oliveira, 2013).

Em outros termos, é possível observar um hibridismo nessas regiões, que constituem "processos socioculturais nos quais estruturas ou práticas discretas, que existiam de forma separada, se combinam para gerar novas estruturas, objetos e práticas" (Canclini, 2013, p. 19). Para esse autor, o convívio e as tensões entre elementos modernos e tradicionais se mostram mais evidentes nessas sociedades complexas inseridas no interior do capitalismo periférico, nos quais os processos socioculturais são resultado de conflitos entre várias forças de origens diversas, tais como a persistência da organização comunitária da economia e da cultura e o poderio do sistema dominante frente a organizações culturais. É o que podemos observar no Agreste de Pernambuco e que torna esta realidade tão rica em termos de estudo e compreensão de seus fenômenos.

Dito isto, é possível afirmar que as práticas sociais inseridas nesses contextos híbridos acabam por assumir prerrogativas também híbridas, como no caso das práticas de trabalho. No contexto do Agreste pernambucano, onde existe ampla manifestação da cultura popular, é possível perceber que nas organizações que desenvolvem o trabalho com cultura popular, os hibridismos entre elementos modernos e tradicionais são evidentes. Isso porque estas organizações têm como base principal crenças e valores tradicionais, entretanto, se veem cada vez mais impulsionadas a desenvolverem conhecimentos e atividades modernas para sobreviverem num mundo global (Gameiro, Menezes, \& Carvalho, 2003; Madeiro \& Carvalho, 2003; Santos \& Costa, 2015). Para compreender o que constitui o moderno e o tradicional, e como as práticas híbridas são formadas, elaboramos uma proposta de análise a partir dos conceitos weberianos de ethos e ação social, conforme explorado no referencial teórico deste trabalho.

Neste artigo entendemos ainda a cultura a partir de sua concepção antropológica, como “um complexo que inclui conhecimentos, crenças, arte, moral, leis, costumes ou quaisquer outras capacidades ou hábitos adquiridos pelo homem membro de uma sociedade" (Laraia, 1986, p. 25). A cultura popular, por sua vez, é entendida como um "conjunto disperso de práticas, representações e formas de consciência" que possuem uma lógica própria, o que ela chama de "jogo interno do conformismo, do inconformismo e da resistência", que se distingue da cultura dominante justamente por essa lógica de práticas, representações e formas de consciência (Chaui, 1989, p. 25). Para esta autora, do campo da filosofia, a grande diferença entre a cultura popular e a cultura erudita, dominante ou de elite, é que esta última é realizada por aqueles que detêm o monopólio do saber, saber este que se torna consequentemente instrumento de poder.

Dessa forma, entender estes hibridismos nas práticas de trabalho de organizações de cultura popular localizadas no Agreste pernambucano se mostra um esforço importante para o desenvolvimento de conhecimento numa realidade organizacional e regional pouco explorada pelos estudos em administração. Entretanto, para além da compreensão dos hibridismos, Greenwood, Raynard, Kodeih, Micelotta e Lounsbury (2011) apontam para a importância de entender também a forma como as organizações respondem a esses conflitos entre lógicas, uma vez que os sujeitos sociais em suas práticas de trabalho possuem agência.

Dito isto, a pergunta de pesquisa que orienta o presente artigo é "como os hibridismos entre ethos tradicionais e modernos estão presentes nas práticas de trabalho da cultura popular no Agreste pernambucano?" Diante dessa pergunta, o objetivo é compreender o hibridismo tradicional-moderno nas práticas de trabalho da cultura popular no Agreste pernambucano e as respostas dadas a estes hibridismos, a partir do estudo de duas organizações culturais: uma banda de pífano e o grupo bumba-meu-boi. Para a realização deste trabalho, demos 
foco às noções teóricas de prática, dentro da perspectiva dos Estudos Baseados em Prática (EBP) e, mais especificamente, a partir da contribuição teórica da etnometodologia; além da compreensão de ethos e ação social de Weber $(2005,2014)$. Optamos pelos EBP e pela etnometodologia por acreditarmos que estes permitem uma aproximação com o cotidiano, tornando mais rica a compreensão da realidade social, principalmente por permitir uma leitura que se esforça em acompanhar a fluidez e as incertezas dos fenômenos sociais (Nicolini, 2013). Max Weber, por sua vez, foi escolhido nesta pesquisa por permitir que se observe a realidade social de forma relacional, ou seja, considerando a importância da agência e da estrutura social, além de permitir a compreensão do que caracteriza o moderno e o tradicional.

A seguir, discutimos teorias de diversos campos do conhecimento, que fundamentam esta pesquisa, propondo uma abordagem multi e interdisciplinar para o estudo do fenômeno em questão, dada a sua complexidade.

\section{Práticas Híbridas: Uma Proposta de Análise a partir das Noções Weberianas de Ethos e Ação Social}

Uma vez que trabalhamos com a noção de práticas de trabalho, é importante esclarecer o significado de práticas. Conforme ressaltam autores como Bispo (2013) e Nicolini (2013), a abordagem das práticas constitui um verdadeiro guarda-chuva que abarca diferentes teorias. Tais teorias muitas vezes optam por compreensões distintas até mesmo sobre a própria ideia de prática, por ressaltarem certos componentes desta e não outros. Nesta pesquisa, buscamos um conceito de prática que estivesse próximo do fenômeno em estudo, nomeadamente, os hibridismos existentes na cultura popular.

Em termos teóricos, compreendemos que as práticas se referem às "performances duráveis, inscritas nos corpos e mentes humanas, objetos e textos, e atados em conjunto de tal forma que os resultados de um desempenho tornam-se o recurso por outro" (Nicolini, 2013, p. 9). Em outras palavras, uma prática é um conjunto de atividades relativamente estável no tempo, que ordena elementos heterogêneos (os corpos e mentes humanas, objetos e textos) em um conjunto coerente, e que dá estrutura e significado para o que as pessoas fazem (Nicolini, 2013; Bispo, 2013). Estar inserido numa prática, portanto, implica aceitar certas normas do que é certo e errado, bem como determinadas maneiras de querer e de sentir (Nicolini, 2013).

A noção do que são as práticas possui influências de várias abordagens, tais como do marxismo, uma vez que se entende que a prática é uma rede de atividade em que conhecimento não está separado de fazer; da fenomenologia, visto que se entende que sujeito e objeto são parte de um contexto social e histórico em que não há dualismos; do interacionismo simbólico, pois a noção de prática entende que os seres humanos agem com base nos significados que eles constroem em interação com os grupos dos quais pertencem; do legado de Wittgenstein, dado que os significados das práticas se dão através de jogos de linguagem; do pós-humanismo de Latour, em razão de as práticas considerarem a agência dos humanos e não humanos (Bispo, 2015).

Desse modo, observam-se várias abordagens para o mesmo tema, o que não se pretende explorar nesta pesquisa, mas sim, em que medida a noção de prática ajuda a compreender a realidade híbrida das organizações de cultura popular no Agreste pernambucano.

Apesar de possuir uma compreensão muito específica sobre o que são as práticas, associandoas à teoria cultural, Reckwitz (2002), sociólogo cujas pesquisas têm proporcionado importante contribuição na área de administração, atribui uma noção interessante sobre a ideia de prática (praktik), que seria constituída por comportamentos em certa medida rotinizados, que pressupõem a existência de vários elementos interligados uns aos outros, como atividades corporais, atividades mentais, coisas e seu uso, um conhecimento de fundo, know-how, estados de emoção etc.

Theodore Schatzki (2001), filósofo e importante estudioso dos Estudos Baseados em Prática, por sua vez, afirma que a abordagem prática pressupõe uma ontologia social distinta ao sustentar que o social é um campo de práticas incorporadas e materialmente entrelaçadas organizadas em torno de entendimentos práticos compartilhados. Esta noção chama a atenção para o fato de que prática e agência estão intimamente ligadas por meio do caráter incorporado. Isso significa que a prática só existe porque os agentes sabem como realizá-la e este é um conhecimento que faz o ser humano, suas propriedades físicas, bem como suas capacidades mentais serem forjados na prática (Schatzki, 2001).

Alguns elementos fundamentais constituem as práticas, de acordo com Nicolini (2016): a) Práticas são fenômenos maiores que possuem um número de sub componentes, geralmente chamados atividades; b) As práticas e seus subelementos só adquirem sentido quando organizados 
em torno de um fim; c) Práticas existem em configurações que os autores se referem como nós, redes, nexos, associações ou texturas, ou seja, não existem práticas isoladas; d) Práticas têm uma natureza coletiva e normativa, muitas vezes estando associadas a grupos de referência, que mantêm a prática viva por (re) produção; e) As práticas trazem à tona o papel crítico e ativo das coisas materiais em todos os assuntos sociais; f) Sempre há inconsistências parciais e tensões dentro dos componentes de uma prática e entre diferentes práticas. Os conflitos podem surgir a partir do desalinhamento dos elementos de uma prática, da concorrência entre as velhas e novas formas de fazer as coisas, ou a partir da introdução de novidade, como novas tecnologias ou regras; g) Todas as práticas têm uma história e são historicamente situadas; h) A natureza social e material das práticas também as torna inerentemente situadas em um momento particular no tempo, espaço e história; i) A indeterminação das práticas deixa margem para a iniciativa, criatividade e biografias; j) As práticas e seus agenciamentos capacitam certos cursos de ação em detrimento de outros.

Para operacionalização da presente pesquisa, adotamos a abordagem etnometodológica como orientação para a identificação das práticas estudadas. Para Bispo (2011), a etnometodologia é uma das principais abordagens influenciadoras dos Estudos Baseados em Prática, consistindo tanto em uma abordagem teórica quanto metodológica, o que exige esclarecimentos sobre ela nesta discussão teórica. Segundo este autor, o estudioso que iniciou os estudos sobre a etnometodologia e se tornou a principal referência sobre o assunto foi o sociólogo Harold Garfinkel, que teve como base para a elaboração de suas ideias elementos do interacionismo simbólico da obra de Parsons sobre teoria da ação social, da fenomenologia de Husserl e de Schutz, e da obra de Wittgenstein sobre jogos de linguagem.

A etnometodologia de Harold Garfinkel, em especial, é caracterizada por Maynard e Clayman (1991) como estudos do trabalho capazes de descrever com precisão os cursos da razão prática e a ação incorporada, bem como de analisar os fundamentos envolvidos em determinado trabalho. Para esses autores, tal abordagem, quando adequadamente especificada, com detalhamento e profundidade, possui grande relevância por incrementar a compreensão da organização social e da ordem envolvidas nas práticas cotidianas.

Cinco conceitos são essenciais para a compreensão das práticas por meio da etnometodologia de Harold Garfinkel, de acordo com Bispo e Godoy (2014), Bispo (2011), Adamoglu de Oliveira e Montenegro (2012) e Romero (1991):

a) A prática, no sentido de realização e experiências cotidianas de um grupo. Esse conceito sugere que a principal preocupação da etnometodologia são as práticas corriqueiras da vida cotidiana, partindo muitas vezes daquilo que é tido como senso comum para a análise de crenças, hábitos, atividades etc.;

b) a indicialidade se trata da linguagem em uso, ou seja, dos diferentes significados possíveis da linguagem, a depender do contexto em que é empregada. A questão da indicialidade chama a atenção para como os agentes, em determinado contexto, constroem visões de mundo por meio da criação de expressões que invocam a noção comum sobre o que é e o que constitui sua realidade social;

c) a reflexividade se trata do efeito da prática ao longo do tempo, ou seja, refere-se às propriedades racionais reconhecíveis pelos indivíduos a partir do senso comum que eles possuem nos seus contextos de interação;

d) a relatabilidade, ou accountability, se refere à forma como o grupo justifica as atividades e condutas por meio de uma reflexividade consciente, que pode ser minimamente descrita por meio da linguagem. É o processo de explicação mediante o qual as pessoas dão explicações ao mundo e o modo como os agentes descrevem, analisam, criticam e idealizam situações específicas;

e) a noção de membro se refere àqueles que são do grupo e não apenas estão nele. Esse pertencimento à coletividade pressupõe um estoque de conhecimentos compartilhados sobre o mundo social que permite aos indivíduos agir da maneira que é esperada em determinadas situações.

A partir desses conceitos e entendendo a etnometodologia como uma abordagem guia, realizamos um estudo de orientação etnometodológica, conforme discutimos na seção de procedimentos metodológicos.

As práticas, conforme defendemos neste artigo, podem possuir diferentes lógicas, como no caso das práticas de trabalho desenvolvidas no Agreste pernambucano, que têm em si pressupostos modernos e tradicionais. Para compreender o que é moderno e o que é tradicional, usamos o 
suporte teórico do economista e sociólogo alemão Max Weber $(2005 ; 2014)$ que, no final do século XIX e início do século XX, buscou compreender os fundamentos da ação moderna, no período de ascensão do capitalismo europeu. Duas de suas principais obras neste sentido foram A Ética protestante e o Espírito do Capitalismo, publicada em 1904, e Economia e Sociedade, obra póstuma, publicada em 1920. Para este estudioso, a modernidade se caracteriza como uma forma de agir diferenciada, guiada por um ethos, ou uma ética muito específica, que substitui uma visão tradicional - baseada nas explicações mágicas e sobrenaturais - num processo de desencantamento do mundo. Este ethos está intimamente relacionado à noção de ação social.

A ação é, para Max Weber, o dado central de sua sociologia interpretativa, englobando os vários fazeres individuais e estando relacionada a um sentido subjetivo, que nada mais é que uma atribuição humana a processos e objetos (Silva, 2015). A ação social, por sua vez, compreende aquela cujo sentido é orientado pelo comportamento ou ações de outras pessoas (Weber, 2014) que podem ter acontecido no passado, presente, ou serem esperadas para o futuro, sendo esses "outros" pessoas conhecidas ou desconhecidas, indivíduos ou uma pluralidade deles (Silva, 2015).

A ação social é analisada e explicada a partir de quatro tipos ideais - ou seja, tipos conceitualmente puros (ou tipos ideais) - raramente encontrados na realidade exclusivamente da forma como são propostos:

- A ação racional referente a fins, cujo agente orienta sua ação ponderando os fins, os meios, as consequências secundárias. Em outras palavras, existe uma orientação por expectativas em relação ao comportamento dos objetos exteriores ao indivíduo, sendo estas expectativas utilizadas como meios para alcançar fins próprios, ponderados e perseguidos de forma racional;

- A ação racional referente a valores, cuja ação se orienta e é planejada em relação à convicção do indivíduo em valores, sejam eles éticos, estéticos, religiosos, ou outra causa de qualquer natureza, independente do resultado. Assim, “age de maneira afetiva quem satisfaz sua necessidade atual de vingança, de gozo, de entrega, de felicidade, contemplativa ou de descarga de afetos (seja de maneira bruta ou sublimada)" (Weber, 2014, p. 15);

- A ação tradicional, que é orientada pelo costume arraigado, muitas vezes não passando de uma "reação surda a estímulos habituais que decorre na direção da atitude arraigada" (Weber, 2014, p. 15);

- A ação afetiva, orientada especialmente por aspectos emocionais como os afetos.

Teóricos da sociologia da modernização apontam que a valorização dos atributos ligados ao esforço próprio e à realização pessoal, chamados por Helal (2015) de "papéis adquiridos", é um aspecto fundamental dessa modernização que, conforme discutido acima, atribui relevância exacerbada à ação racional com base nos fins. Neste sentido, uma das marcas dessa modernização seria a substituição dos atributos herdados da família e da origem social, chamados "papéis atribuídos", pela valorização às conquistas individuais (Helal, 2015).

Apesar dessa compreensão sobre o que constitui a modernização, compreendemos que ao longo de suas construções históricas, realidades híbridas como o Brasil e o Agreste pernambucano, estudado neste artigo, atrelaram diferentes tipos de ações sociais. Dessa forma, é possível observar que tanto a ação racional baseada em fins, quanto a ação racional baseada em valores, a ação emotiva e a ação tradicional (Weber, 2014) se entrelaçam e se transformam em lógicas de ação muito próprias, nos contextos mencionados, fugindo de modelos de modernização propostos por teóricos diversos. Tal entrelaçamento entre os diferentes tipos de ações têm em vista objetivos diversos, por vezes atrelados a formações sociais tradicionais (como família, classe), outras vezes atrelados a instituições modernas (como o estado ou o mercado que, apesar de modernos, podem ser comandados por interesses tradicionais, principalmente no contexto nordestino e agrestino).

Dessa forma, entendemos que o que caracteriza a relação entre moderno e tradicional no contexto agrestino (e nas práticas de trabalho com cultura popular) é a convivência/conflito entre ethos caracterizados por lógicas de ação distintas. Em outros termos, a agência social de indivíduos, em determinadas práticas, pode pressupor um ethos cuja base está, em maior ou menor grau, na ação social com base nos fins, valorizando-se o indivíduo e suas conquistas pessoais (o que caracteriza o elemento "moderno" da realidade social), na ação racional baseada em valores, na ação emotiva ou na ação tradicional (as duas últimas aproximam-se do que entendo por "tradicional" no mundo social).

Ressaltamos que, apesar de entender que esses ethos caracterizam o moderno e o tradicional, não entendemos que eles existam de forma dual e polarizada na realidade social. Na verdade, reiteramos o que diz Weber (2014) sobre estes serem tipos essencialmente ideais, ou seja, tipos 
puros conceituais, que não existem na realidade de forma pura, mas sim de forma híbrida, em relações de convívio e conflito.

A fim de evitar uma leitura dicotômica desses ethos, propomos que as práticas de trabalho com cultura popular no Agreste pernambucano sejam analisadas a partir da noção de um continuum. Assim, algumas delas tendem a carregar características mais modernas, ou seja, seguindo um ethos cuja base está na ação racional baseada nos fins, na qual se valorizam os papéis adquiridos (ou seja, as conquistas individuais). Outras podem estar mais próximas de um ethos cuja base é a ação racional com base em valores, que se aproxima de uma noção moderna por ser racional e também pelo fato de certas questões ditas racionais (como a eficiência, a eficácia, a produtividade etc.) serem vistas como verdadeiros valores. Outras práticas ainda podem estar mais próximas de uma noção tradicional, uma vez que se aproximam do ethos cuja base pode estar na ação emotiva ou na ação tradicional, cuja preocupação está mais associada às reações relativas aos sentimentos ou à manutenção de costumes arraigados, crenças, valores familiares e comunitários etc.

A formação histórica e social do Brasil, do Nordeste e, particularmente, do Agreste pernambucano, evidenciam esse hibridismo. Isso pode ser constatado no fato de os valores europeus terem sido inseridos na realidade patriarcal e escravocrata brasileira e isso render até os dias de hoje complexas dinâmicas entre valores impessoais e valores advindos de hierarquias sociais famílísticas e de classe (Souza, 2000). Ou ainda, no fato de uma modernização truncada se dar no Agreste pernambucano, local onde um polo de confecções têxtil tem se desenvolvido, fazendo crescer economicamente a região, mas, por outro lado, as formas de trabalho permanecem informais e precárias, evidenciando grande contradição, como afirma relatório do Serviço Brasileiro de Apoio às Micro e Pequenas Empresas [ SEBRAE] (2013).

Deste modo, busca-se rejeitar a dicotomia existente entre o moderno e o tradicional, tentando perceber como essas duas dimensões se complementam para o desenvolvimento das práticas de trabalho na cultura popular. Entendemos que as interpretações que descartam a racionalização na dimensão dos afetos tornam incompreensíveis os movimentos do fenômeno aqui estudado - a cultura popular (Farias, 2001). Neste sentido, o conceito de modernidade-mundo de Renato Ortiz nos parece pertinente, por compreender uma modernidade que, na verdade, não impõe um absoluto ontológico, mas sedá num movimento refratário que busca se adequar às circunstâncias, na qual múltiplos fatores e forças, de ordens simbólicas e econômicas, sejam locais, nacionais ou globais, atravessam-se continuamente, gerando situações de conflitos diversas (Farias, 2001).

\section{Trabalho na Cultura Popular}

Compreendidas o que significam as práticas híbridas na seção anterior, cabe uma reflexão sobre o trabalho com cultura popular, tendo em vista o objetivo do presente artigo. Blass (2007), em sua pesquisa desenvolvida em escolas de samba, constata que o trabalho nas organizações de cultura popular recobre "um campo amplo de práticas e atividades que extrapola o emprego ou trabalho assalariado nas indústrias e/ ou nas grandes empresas" (p. 119). Nesse contexto, as práticas de trabalho e de emprego aparecem, muitas vezes, "fundidas e misturadas, sem qualquer classificação hierárquica entre os mundos do trabalho e do não trabalho" (p. 122).

Em tese sobre os trabalhadores das indústrias criativas, Souza (2011) ressalta alguns elementos que ajudam a compreender características do trabalho com cultura, mostrando como ele é complexo e de difícil análise, se partirmos da literatura sobre trabalho (moderno) existente. Para ela, esse tipo de trabalho envolve a realização de trabalho autônomo, geralmente com recompensas baixas, o que faz com que as pessoas trabalhem em múltiplas ocupações. Ainda para esta autora, os trabalhadores dessas "indústrias" buscam, em sua maioria, a satisfação não econômica, possuem foco na qualidade de vida, e geralmente se envolvem em vários projetos diferentes - os chamados projetos culturais.

O trabalho criativo (que, em alguns aspectos, pode ser entendido como trabalho com cultura) tem na colaboração um elemento recorrente, visto como uma forma de escapar à concorrência característica dos setores estritamente econômicos. A criação, neste tipo de trabalho, portanto, estaria em constante equilíbrio entre as autorias insulares e as colaborativas (Almeida \& Pais, 2012). Além disso, este trabalho é marcado por um forte senso de autonomia, no qual o trabalhador consegue integrar a criação, a produção, a distribuição e o consumo, caráter este constantemente apropriado pela lógica capitalista, separando esses momentos e tirando a autonomia do trabalhador, de acordo com Canclini (2013). 
Além disso, o trabalho com cultura envolve especificidades em relação a trabalhos desenvolvidos em organizações formais, tais como: os trabalhadores recorrentemente buscam maior realização profissional através do seu trabalho; desprezam o trabalho formal, ou trabalho comum; sentem necessidade de aliar trabalho e prazer; veem no trabalho com cultura maior possibilidade de autonomia; trabalham em oscilações entre autorias insulares e autorias colaborativas, tendo a colaboração um importante papel na conjuração da competição; veem no seu trabalho uma possibilidade de transformação da realidade (Dourado, Holanda, Silva \& Bispo, 2009; Gubert \& Kroeff, 2001; Almeida \& Pais, 2012; Fischer, 1987).

O trabalho artístico (que entendo aqui como trabalho com cultura) é ainda feito de incerteza e esta incerteza é uma condição da inovação, da invenção original e da satisfação sentida ao criar (Menger, 2005). Para este autor, é a possibilidade do trabalho imaginário de inventar e experimentar que permite o sentimento de liberdade que caracteriza o trabalho artístico.

Nas manifestações de caráter cultural e popular, o lúdico se transforma em trabalho e o prazer da exibição artística em obrigação contratual (Gameiro et al., 2003), o que o diferencia do trabalho realizado em organizações formais e de natureza empresarial. Além disso, o trabalho no âmbito dos coletivos de cultura popular não está limitado ao sentido economicista e alienante, de acordo com Holanda (2011). Para esta autora,

As manifestações de cultura popular são de autoria anônima e a produção cultural nos coletivos não é vinculada à propriedade. Ao invés de atividade alienante, o trabalho consiste em ação orientada pela autorrealização, valorização de identidade cultural e "empoderamento" dos sujeitos que movem os coletivos. A maioria não consegue sobreviver apenas da atividade cultural e exerce algum ofício no mercado de trabalho para sustentar a família (Holanda, 2011, p. 219).

Apesar dessa característica mais voltada para elementos subjetivos, de identidade e autorrealização, o trabalho com cultura se relaciona com elementos modernizantes, mais objetivos e racionais. Sobre isso, Menger (2005, p. 21), referindo-se à cultura de forma ampla (e não à cultura popular, em sentido estrito), afirma:

A visibilidade simbólica do sistema de trabalho artístico compreende a natureza paradoxal das formas de atividade nas quais a arte é o centro: autonomia na relação de trabalho e realização através do desenvolvimento pessoal na atividade são os ideais reguladores do ato de trabalho artístico. As tomadas de risco associadas à imprevisibilidade do sucesso, projeto após projeto, e as fortes pressões concorrenciais criadas e exploradas pelo sistema de emprego traçam um retrato singular do artista como profissional qualificado e audacioso, livre e individualista simultaneamente desinteressado e indiferente às "necessidades materiais" de uma escolha profissional aleatória, pelo menos no início do seu compromisso, visto que o sucesso é intrinsecamente incerto [...] A organização do trabalho artístico segundo a lógica de projetos e as formas de emprego e de relações de trabalho que lhe são ligadas conferem além disso, para o melhor e para o pior, uma posição muitas vezes qualificada de pioneira [...] aos artistas transformados em encarnações idealizadas [...] de trabalhadores móveis, polivalentes, responsáveis, aptos para os desafios e conscientes das ambivalências dos métiers com forte potencial inovador.

Essas pressões concorrenciais e essa inserção na lógica de projetos parecem ser elementos modernos presentes no trabalho com cultura como um todo, inclusive no trabalho com cultura popular, conforme discutido por Madeiro e Carvalho (2003) e Holanda (2011). É o que Almeida e Pais (2012) denominam "profissionalização da criatividade", ou seja, a atribuição de uma envergadura profissional, característica das organizações empresariais, para atividades criativas (e culturais). Já a atribuição de "posição qualificada" aos artistas devido às suas características de trabalho, associa-se ao fenômeno de "criativização da profissão", que estaria transferindo valores criativos (e culturais) às empresas (Almeida \& Pais, 2012).

Nesse sentido e voltando mais especificamente para a cultura popular, trabalhar neste segmento na contemporaneidade, produzindo obras significativas, comunicando-se com o público etc., tornou-se muito mais complicado, de acordo com Canclini (2013), devido às mudanças e exigências de um contexto global. Para ele, da mesma forma que artesãos ou produtores das culturas populares já não podem apenas se referir ao seu universo tradicional, os artistas também não podem se fechar em seus campos. Dessa forma, o popular, mediado por uma reorganização mercantil e espetacular dos processos simbólicos, necessita e se utiliza de novas estratégias, que vão, geralmente, no sentido de reconversão do patrimônio tradicional para se inserirem na lógica moderna do contexto contemporâneo, em um processo de hibridação. 
Assim, entende-se que organizações que possuem práticas culturais tradicionais mudam conforme as transformações do contexto no qual se inserem (Figueiredo, 2016). Para esta autora, "os riscos de perda cultural, os quais se asseveram diante do acelerado processo de modernização das culturas tradicionais estabelecem mecanismos de resistência, resiliência e adaptação, propiciando que a prática sobreviva, e se transforme" (Figueiredo, 2016, p. 41-42). Este caráter de resistência, apropriação e transformação é essencial para a compreensão das práticas das organizações de cultura popular na contemporaneidade, que transformam cotidianamente suas tradições, articulando-as aos elementos modernos acessados.

Trabalhos anteriores já se propuseram a compreender a dinâmica entre manifestações populares tradicionais e a lógica moderna no contexto brasileiro. Ao estudar as festas populares e a economia simbólica, Farias (2005, p. 649) observa a existência de uma "teia coligando núcleos formais e informais jurídico-institucionais de graus e naturezas distintas, mas orientadas para o lucro obtido por intermédio da prestação de serviços monetizados de diversão, integrando a dimensão da modernização capitalista". Neste sentido, o autor estuda a espetacularização das festas populares na chamada indústria do entretenimento-turismo.

Em estudo recente, Dalmoro e Nique (2017) discutem a mercantilização da tradição como um fenômeno importante para a compreensão das práticas de mercado. De acordo com os autores, que estudaram o contexto das tradições culturais gaúchas, o mercado tem um papel importante na manutenção das tradições locais, por meio da tangibilização da tradição, promovida pelo mercado, pela aproximação entre tradição e consumidores e pela exaltação dos elementos ligados à identidade gaúcha.

Ao buscar entender como ocorrem esses processos de mercantilização (apesar de não utilizar necessariamente este termo), Mira (2014) investiga a retomada da "tradição" nas grandes metrópoles por meio de processos de mediação, ou seja, processos de transmissão de práticas culturais. Para esta autora, determinadas metrópoles se especializam na reinvenção das tradições:

Nos espaços 'requalificados', a 'cultura popular' aparece transfigurada pela intervenção de artistas plásticos, decoradores, designers, estilistas, expositores, cenógrafos, chefes de cozinha e outros profissionais a serviço do mundo do consumo e do 'entretenimento-turismo' (Mira, 2014, p. 199).

Seriam essas intervenções e modificações, promovidas pelos diversos agentes culturais, os próprios processos mediadores, que transformariam continuamente as tradições (Mira, 2014). Tal noção complementa, em certa medida, o argumento do presente artigo, de que práticas híbridas, ou seja, práticas que mesclam diferentes ethos, constituem o trabalho com cultura popular. Neste sentido, é correto afirmar que nenhuma prática é puramente tradicional, ou seja, exatamente igual aos costumes e normas vigentes no passado, pois o elemento "tradicional" está sempre sofrendo interferências e sendo ressignificado, muitas vezes em função de elementos modernos.

Apesar de esses estudos serem de extrema relevância para a compreensão das possíveis formas de interação entre os elementos modernos e tradicionais nas práticas culturais, o contexto investigado, nomeadamente, o Agreste de Pernambuco, possui particularidades no que se refere ao desenvolvimento do trabalho com cultura e de um "mercado cultural" ou "mercado do entretenimento". Na apresentação das práticas das organizações estudadas e na posterior discussão empreendida, buscamos ressaltar essas especificidades locais.

\section{Procedimentos Metodológicos}

A abordagem epistemológica adotada nesta pesquisa é a dos próprios Estudos Baseados em Prática. Tal "paradigma" foge do estruturalismo e do subjetivismo (Schatzki, 2001; Nicolini, 2009; 2013; Nicolini \& Monteiro, 2015; Bispo, 2013; 2015). Compreende que a realidade não pode ser limitada à noção de que a estrutura define as dinâmicas sociais, nem à noção única de que o ser humano constrói a realidade por meio de sua subjetividade. Na verdade, compreende-se que os fenômenos sociais devem considerar ambas perspectivas analíticas, considerando a existência de uma recursividade entre agência e estrutura.

Em outros termos, a abordagem epistemológica dos Estudos Baseados em Práticas compreende que o nível micro e o nível macro de compreensão do social estão em constante interação. Tais níveis, na verdade, não existem no cotidiano, sendo apenas conceitos abstratos e didáticos utilizados para facilitar a compreensão em termos teóricos. 
Como é possível observar na fundamentação teórica deste trabalho e como será possível observar nos procedimentos metodológicos, as escolhas foram feitas no sentido de superar as dualidades existentes na compreensão do mundo social, e quando mencionamos conceitos duais como moderno e tradicional, micro e macro - utilizamos apenas como recurso didático utilizado para tornar possível a compreensão dos hibridismos que buscamos analisar.

A etnometodologia foi escolhida como principal abordagem teórica e metodológica dessa pesquisa, por ser uma das principais correntes de pensamento influenciadoras dos Estudos Baseados em Prática (Bispo, 2011). O grande objetivo dessa vertente da etnometodologia, de acordo com Bispo e Godoy (2014, p. 113) é "investigar os procedimentos que as pessoas utilizam para desenvolver as diferentes operações que realizam em sua vida cotidiana". Dessa forma, o autor e a autora destacam que é possível analisar "as maneiras habituais de proceder que são mobilizadas pelos atores sociais enquanto membros de uma sociedade ou grupo". As descrições da vida social corrente, possibilitadas pela etnometodologia, dão acesso, portanto, às atividades cotidianas enquanto fenômenos socialmente organizados (Romero, 1991).

Compreendidas tais abordagens, optamos por realizar pesquisa essencialmente qualitativa, por compreender que este tipo de pesquisa possui algumas características-chave, que vão ao encontro do propósito da presente pesquisa, a saber: tem como foco na compreensão de que as pessoas dão sentido a suas vidas, permitindo o delineamento do processo de construção de significados e a descrição de como as pessoas interpretam suas experiências; o pesquisador é o instrumento primário da coleta e análise de dados; o processo é indutivo; o produto da investigação qualitativa é ricamente descritivo; o design da pesquisa é emergente e flexível; o pesquisador ou pesquisadora precisa ter sensibilidade para fazer boas questões e observações cuidadosas (Merriam, 2009).

O contexto e os sujeitos selecionados para a realização da pesquisa empírica foram duas organizações de cultura popular: uma de bumba-meu-boi e outra, uma banda de pífano, localizados na cidade de Caruaru, no Agreste do estado de Pernambuco. Esta cidade é a principal do Agreste pernambucano em termos demográficos (Silva, Sobral, \& Santana, 2012) e constitui um caso emblemático do hibridismo existente no Nordeste brasileiro. As duas organizações culturais foram escolhidas em função da facilidade de acesso e por serem dois dos grupos mais antigos atuantes na cidade de Caruaru - o de bumba-meu-boi possuía mais de 90 anos em 2016, e a banda de pífano, mais de 80 anos.

Bispo e Godoy (2014) propõem que uma coleta de informações baseada em etnometodologia deve considerar observação participante, conversas informais, entrevistas individuais ou coletivas, diário de campo e análise de documentos, todos envolvendo autorreflexão. Neste sentido, foram realizadas entrevistas semiestruturadas, seguindo roteiro com questões chaves sobre a história e o dia a dia das organizações, mas passíveis de alterações ao longo do ato da entrevista. As entrevistas duraram de 25 minutos (menor tempo de entrevista) a 60 minutos (maior tempo de entrevista) e foram realizadas nas duas sedes da organização do bumba-meu-boi e na sede da banda de pífanos. Essas entrevistas foram gravadas e transcritas pelos autores, para posterior análise. Conversas informais também aconteceram com os agentes em campo, nas quais não se seguiu um roteiro. Dada a espontaneidade dessas conversas informais, não foi possível gravá-las, nem mensurar seu tempo de duração, somente anotar insights dos autores a partir delas nos diários de campo. Tais conversas aconteceram numa das sedes do bumba-meu-boi, localizada na casa da Sra. DL, também conhecida como a matriarca do boi; na sede da banda de pífanos; em diferentes bairros da cidade de Caruaru-PE, durante cortejo do bumba-meu-boi; e na casa de um amigo dos integrantes do boi, durante concentração para cortejo na cidade de Olinda-PE.

As entrevistas semiestruturadas e as conversas informais aconteceram com os líderes das organizações mencionadas (Sr. RG, líder do bumba-meu-boi, integrante do grupo há mais de 40 anos, e com mais de 50 anos de idade; e Sr. AP, líder da banda de pífano, integrantes da mesma há cerca de 5 anos e com cerca de 30 anos de idade) e outros cinco integrantes das organizações, que também desenvolvem atividades de organização e coordenação (Sr. MA, Sr. ZG e Sr. MS, irmãos e integrantes da banda de pífano desde a infância, com cerca de 70, 60 e 50 anos, respectivamente; e Sra. ZZ e Sra. DL, irmã e mãe, respectivamente, do Sr. RG, ambos coordenadores do bumba-meu-boi pesquisado desde a década de 1970).

A organização de banda de pífano possuía em 20164 integrantes e todos eles foram entrevistados. A organização de bumba-meu-boi, por sua vez, possuía mais de 40 integrantes na época da realização da pesquisa, e optamos por entrevistar aqueles que desenvolviam atividades de organização e coordenação, ou seja, planejamento as atividades, contato com parceiros, representação pública da organização, desenvolvimento de projetos etc. Foram selecionados também aqueles que puderam conceder entrevistas no período de confecção dessa pesquisa, que 
aconteceu entre dezembro de 2015 e abril de 2016. Os nomes das organizações, dos entrevistados e entrevistadas foram mantidos em sigilo, com a finalidade de não expor os agentes envolvidos.

Observações participantes em eventos de cultura popular na cidade de Caruaru também foram realizadas, nomeadamente em um fórum setorial de cultura popular e um fórum setorial de povos tradicionais, três reuniões do Conselho Municipal de Cultura de Caruaru, dois encontros de capacitação para o Fundo de Cultura do Estado de Pernambuco (Funcultura), dois cortejos do bumba-meu-boi, evento de carnaval da cidade organizado pela banda de pífano, aulas de pífano e apresentação do bumba-meu-boi para programa televisivo. Acreditamos, nesta pesquisa, que toda observação é participante, tendo em vista que o pesquisador interage, em maior ou menor grau, com os sujeitos estudados (Bourdieu, Chamboredon \& Passeron, 2007).

Buscamos observar as atividades que os trabalhadores da cultura popular desenvolvem no seu trabalho e também as interações estabelecidas por meio de vivência intensiva no campo. Ressaltamos aqui que essas observações, bem como as entrevistas, foram realizadas no sentido de perseguir as práticas desenvolvidas por estas pessoas e não as pessoas em si, conforme recomendam os estudos que utilizam a abordagem das práticas (Bispo, 2015; Nicolini, 2009).

Tais observações foram registradas em diário de campo, seguindo a proposta de Angrosino (2009) para sistematização das anotações de campo, ou seja, relatando a explicação do cenário; a relação entre os participantes; a descrição dos participantes; a descrição do cenário físico e dos objetos materiais que o compõem; a descrição dos comportamentos e das interações; e os registros de conversas e de outras interações verbais. Além disso, impressões dos pesquisadores também foram registradas. Ao todo, foram geradas 15 notas de campo em formato de textos. Essas notas preencheram um caderno inteiro com 56 laudas (com dimensões de 17 centímetros de comprimento e 11 centímetros de largura) e 26 laudas de outro caderno (com dimensões de 25 centímetros de comprimento e 16 centímetros de largura).

As práticas foram identificadas a partir de análise e interpretação de orientação etnometodológica, seguindo orientação de Bispo e Godoy (2014). Assim, consideramos como uma prática um conjunto de atividades desenvolvidas pelos membros, que compartilham de um conjunto de significados e de uma linguagem em comum. Em outros termos, a prática, na perspectiva etnometodológica, é entendida como a realização de experiências cotidianas por um grupo, partindo muitas vezes daquilo que é tido como senso comum para a análise de crenças, hábitos, atividades etc. (Bispo \& Godoy, 2014; Adamoglu de Oliveira \& Montenegro, 2012).

Neste sentido, as categorias analíticas utilizadas foram provenientes da noção etnometodológica sobre práticas, ou seja, analisamos as informações coletadas nas entrevistas, conversas informais, anotações em diários de campo, a partir das categorias prática, membros, significados compartilhados(referente à relatabilidade e reflexividade)e linguagem em comum (referente à indicialidade),categorias estas provenientes dos conceitos esclarecidos na fundamentação teórica deste trabalho.

Desse modo, todas as informações coletadas passaram por triagem, considerando as diferentes práticas em que se enquadravam, os diferentes significados compartilhados a que se referiam, as diferentes linguagens utilizadas etc. Tais práticas foram nomeadas pelos autores após a reunião de todas as informações a seu respeito e a identificação de seus sentidos comuns. Ressaltamos que esta não é uma pesquisa etnometodológica pura, mas de orientação etnometodológica, por utilizar como base categorias provenientes dos seus conceitos principais.

Deste modo, foi possível identificar sete práticas, cada uma com membros, significados e linguagens específicos, a serem detalhados na seção de análise: Prática da participação da sociedade civil na construção de políticas públicas de cultura; Prática de elaboração de projetos culturais; Prática de apresentações em locais fixos; Prática do cortejo do bumba-meu-boi; Prática de preparação para as apresentações e cortejos; Prática de construção dos instrumentos; Prática das aulas de pífano.

Após a identificação das práticas, os hibridismos foram analisados para cada uma delas a partir da proposta de análise apresentada na seção "Práticas híbridas: uma proposta de análise a partir das noções weberianas de ethos e ação social". Nesse sentido, utilizamos a noção do continuum, composto pelos ethos moderno e tradicional em suas extremidades e pelas ações sociais (a racional referente a fins e a valores, a ação emotiva e a ação tradicional), proposto na referida seção, para interpretar as falas, objetos, cenários e textos diversos que compõem cada uma das sete práticas, identificando em que momentos elas podem ser consideradas mais modernas ou mais tradicionais. A ideia da análise das práticas a partir dessa noção de continuum proposta, utilizando os conceitos weberianos, é esclarecer que o fenômeno estudado contém, ao mesmo tempo, elementos modernos 
e tradicionais, constituindo verdadeiros processos híbridos, conforme conceito de Canclini (2013) utilizado nessa pesquisa.

A seguir, as práticas são apresentadas, bem como os hibridismos analisados.

\section{As práticas de trabalho da cultura popular no Agreste pernambucano}

Nesta seção, apresentamos as diferentes práticas de trabalho da cultura popular no Agreste pernambucano identificadas, os hibridismos entre elementos modernos e tradicionais encontrados em cada prática, bem como as respostas dadas pelos indivíduos a estes hibridismos.

\subsection{Prática da Participação da Sociedade Civil na Construção de Políticas Públicas de Cultura}

Dois momentos são fundamentais para a concretização dessa prática: as reuniões do Conselho Municipal de Cultura e as reuniões dos fóruns setoriais das culturas populares e dos povos tradicionais. Em ambos os fazedores da cultura popular se reúnem, ora entre si, ora com outros fazedores de cultura de outros segmentos (como música, design e moda etc.), para discutir suas principais demandas e como satisfazê-las com o suporte das políticas públicas.

As atividades que compõem esta prática, observadas durante interação em campo e registradas pelos pesquisadores em diários de campo, são: convidar os integrantes da cultura popular a participarem dos fóruns setoriais, pensar as pautas desses fóruns, presidi-las, elaborar ofícios nos quais constam as demandas daqueles que compõem a cultura popular, coletar assinaturas, entregar tais ofícios aos representantes do poder público, participar das reuniões, assinar os documentos, expor opiniões sobre os assuntos discutidos etc.

As ações existentes nesta prática (como a elaboração de ofícios e o recurso recorrente a leis, registradas em diários de campo e provenientes de observações) nos levam a sugerir que existe a predominância de um ethos com orientação moderna, no sentido de que os agentes pensam em objetivos a serem alcançados e nos meios necessários para alcançá-lo. Um exemplo disso foi a solicitação dos participantes das reuniões do conselho municipal de cultura para ter acesso ao projeto de revitalização da Estação Ferroviária da cidade, onde ficam localizadas a sede da banda de pífano e do bumba-meu-boi, realizado pela prefeitura e enviado ao Instituto do Patrimônio Histórico e Artístico Nacional (IPHAN), por exemplo. Nesse caso, foram acionados recursos como a elaboração de ofício por parte dos conselheiros de cultura popular e povos tradicionais (Sr. AP e Sr. AN, respectivamente) direcionado ao poder público, a coleta de assinaturas de todos os presentes nos fóruns e a solicitação de espaço de voz em reunião na câmara dos vereadores em momento posterior ao fórum.

Os agentes que realizam a mediação entre os integrantes da cultura popular e o poder público (e que são também os gestores e/ou líderes de grupos específicos, como Sr. AP, da banda de pífanos, e também conselheiro de cultura popular do Conselho Municipal de Cultura e o Sr. RG, do bumba-meu-boi e vice conselheiro de cultura popular no Conselho Municipal de Cultura) parecem estar mais conscientes de como os artistas podem se beneficiar dos elementos modernos (marcado pela ação racional com base em fins, mencionada no parágrafo anterior) para garantir que a tradição da cultura popular se mantenha. Assim, eles conseguem, em suas ações, "caminhar" por vários ethos, ora numa orientação mais moderna, ora numa orientação mais tradicional. Como mencionado pelo Sr. AP no I Fórum Setorial dos Povos Tradicionais, "é através do passado que o moderno se recarrega para projetar o futuro" (Nota de Campo, 19 de janeiro de 2016), ou seja, ele demonstra reconhecer como o passado, o moderno e o futuro podem dialogar.

Neste sentido, é possível vislumbrar a existência de um hibridismo entre o moderno e o tradicional nessa prática em específico, visto que a ação racional com base nos fins é utilizada para garantir que manifestações tradicionais, como os cortejos dos bois ou as apresentações de pífano sejam realizadas, mas não de forma "invisível" e sim tendo cada vez mais espaço, seja nos grandes eventos ou em outras ocasiões. A demanda pela criação da Secretaria Municipal de Cultura para adesão ao Sistema Nacional de Cultura e recebimento de verbas do Ministério da Cultura para investimento na cultura local, feita pelo Sr. AP nas reuniões do Conselho Municipal de Cultura, é um exemplo disso. Entendemos que a própria ação dos conselheiros e de outros líderes de grupos culturais, como o Sr. RG, líder do bumba-meu-boi estudado, constituam uma resposta a este hibridismo, uma vez que eles buscam, de forma racional com base em fins, seja por meio de elaboração de projetos, ofício etc., manter os folguedos tradicionais que representam.

A demanda por seleção via edital para participação de artistas no evento do São João de Caruaru, discutida durante os fóruns, também é um bom exemplo desse hibridismo, uma vez que se 
pretende que o uso de um instrumento moderno (no qual é avaliado o mérito de cada proponente, conforme discussão de Helal (2015) sobre o que constitui a modernidade) sirva como base para a participação de manifestações tradicionais numa festa que tem tomado proporções cada vez menos tradicionais e mais modernas, no sentido de que possui interesses políticos e de Mercado fortemente envolvidos.

\subsection{Prática de Elaboração de Projetos Culturais}

A prática de elaboração de projetos culturais também é recente para a cultura popular. Várias atividades compõem esta prática, tendo sido identificadas nesta pesquisa as capacitações para redigir projetos, a redação do projeto, a prestação de contas, a busca de auxílio contábil e jurídico. Cada projeto atende a um edital específico, com regras bem delimitadas, como o edital do Fundo de Cultura do Estado de Pernambuco (Funcultura), ou do Programa Cultura Viva, iniciativa do Governo Federal, por meio do Ministério da Cultura, que dá suporte financeiro a grupos de cultura popular já existentes.

Redigir o projeto envolve certa familiaridade com proposições claras e objetivas através da elaboração de objetivos, justificativa e contextualizações, conforme foi possível observar no encontro de capacitação para o Fundo de Cultura do Estado de Pernambuco (Funcultura) (Nota de campo, 28 de janeiro de 2016). A elaboração do orçamento, na redação do projeto é, em especial, uma atividade crítica, que exige uma familiaridade com questões de impostos, de previsões sobre preços futuros, de sistematização de processos, que nem todas as pessoas possuem, e isso faz com que muitos artistas busquem apoio de profissionais do ramo contábil ou jurídico, como afirmaram Sr. AP (entrevista, 13 de fevereiro de 2016) e Sr. RG (entrevista, 20 de fevereiro de 2016). Dessa forma, é possível constatar o predomínio de uma linguagem técnica e burocrática nesta prática.

Sendo assim, percebemos, por meio dos discursos constantes nos editais e exigidos nos projetos, que a prática de elaboração de projetos aproxima-se de um ethos com orientação moderna, na qual predomina a ação racional com base em fins (Weber, 2014). Isso porque o projeto deve conter, de forma clara, sistemática e objetiva, o objetivo a ser alcançado e a forma detalhada de alcance dele. Além disso, é uma prática que se associa à concepção do que é moderno também por visar um julgamento baseado no mérito do proponente do projeto, preocupando-se mais com a questão do desempenho pessoal, substituindo a importância dos atributos herdados da família e da origem social, pela valorização dos atributos ligados ao esforço próprio (Helal, 2015).

Isso gera conflito para os agentes da cultura popular, principalmente entre aqueles que sabem elaborar projetos e aqueles que não detém este saber. Como mencionado na fala do Sr. AP (entrevista, 13 de fevereiro de 2016), acaba existindo uma perpetuação dos mesmos produtores culturais, que sempre aprovam projetos.

Outro aspecto que caracteriza a modernização dessa prática é o próprio contexto de elaboração dos discursos que compõem a prática de elaboração de projetos, ou seja, o discurso referente a orçamentos, impostos, detalhamento de processos etc. Este é um discurso elaborado e difundido em espaços empresariais e de caráter jurídico por excelência, não sendo comum no espaço da cultura popular.

Essa predominância de características modernas, entretanto, não anula a existência de elementos tradicionais nesta prática, que é principalmente o conhecimento do fazer cultural, geralmente passado "de pai para filho", que constitui a essência dos projetos culturais. Sem este conhecimento não é possível elencar os materiais e pessoas necessários, muito menos elaborar objetivos e justificativas para o projeto. Logo, é possível observar que existe uma convivência entre elementos modernos e tradicionais nesta prática.

Diante disso, um indicativo do hibridismo entre tradicional e moderno existente nesta prática está no fato de o discurso próprio da elaboração de projetos poder acontecer também em ambientes mais informais, como numa reunião entre os agentes na casa de um deles, no qual estas questões são discutidas de maneira informal e às vezes sem foco, de uma maneira muito própria, como já indicado em pesquisa por Holanda (2011). Isto pode ser considerado como uma intertextualidade, uma vez que discursos próprios do campo gerencial e do management são utilizados em outros contextos, no caso aqui analisado, o contexto da cultura popular, no qual o discurso lúdico lhe é mais característico. Assim, é possível entender que os artistas que compõem a cultura popular encontram seus próprios meios de lidar com a convivência (asvezes conflituosa) entre os elementos modernos e tradicionais expostos. 
Dito isto, interpretamos essas formas de fazer projetos, marcadas pela informalidade, como discute Holanda (2011); as parcerias dos artistas da cultura popular com os produtores culturais e o crescimento desses profissionais na cultura popular como discutido por Santos (2013) e a busca por auxílio contábil e jurídico como as principais respostas ao hibridismo inerente à prática de elaboração de projetos culturais.

\subsection{Prática de Apresentações em Locais Fixos}

No pífano, as bandas se apresentam, em geral, em locais fixos, eventos e shows. As bandas são compostas tradicionalmente por um zabumbeiro, um tocador de caixa de guerra, um tocador de contrassurdo e um ou dois pifeiros - que tocam o pífano. Em outros momentos, entretanto, eles utilizam instrumentos adicionais como os pratos, o pandeiro e/ou triângulo durante as apresentações.

As músicas são a principal linguagem usada pelas bandas de pífano, constituindo uma linguagem essencialmente lúdica, e as atividades relacionadas a esta prática dizem respeito principalmente à execução dos instrumentos. Suas apresentações acontecem em vários festejos e muitas vezes nas feiras de Caruaru, como fica claro na fala de um dos mestres da banda (Sr. ZG, entrevista, 20 de fevereiro de 2016). Entretanto, existe uma forte associação das bandas de pífano com as festividades juninas de Caruaru, associação feita desde a época em que estas bandas começaram a se apresentar na cidade. Esta associação se estende para festas de caráter popular em geral, que podem ser religiosas e lúdicas, possuindo, conforme Canclini (1995) caráter coletivo, sem exclusão de classes, sendo a expressão de uma comunidade local, realizadas geralmente em espaços abertos ao ar livre.

Para o Sr. AP (entrevista, 13 de fevereiro de 2016), as pessoas que promovem a cultura na cidade e os próprios artistas fortalecem esta noção, o que, para ele, é um erro, porque limita a amplitude de ação das bandas de pífano. É neste sentido que este representante da cultura popular tem buscado inserir as bandas de pífano em vários outros eventos da cidade.

Além disso, o próprio evento do São João da cidade de Caruaru, que em sua origem possuía caráter popular em essência, hoje tomou novas proporções. Este evento é marcado sobretudo pelos grandes shows com artistas nacionais, que atraem grandes públicos. Tendo em vista a grande quantidade de pessoas atraídas por estes grandes shows, grandes empresas patrocinam o evento, tornando-o uma forma de expor sua marca. Neste sentido, o evento do São João de Caruaru, em sua origem religiosa e popular, já não possui mais essa marca evidente.

Assim, é possível observar uma característica híbrida dessa prática: enquanto existe uma associação das apresentações das bandas de pífano aos festejos religiosos e populares, como os juninos, baseada essencialmente em costumes do Nordeste brasileiro - o que caracteriza um ethos com orientação tradicional - existe uma necessidade de os grupos possuírem recursos financeiros para se manterem ao longo do ano, o que constitui uma orientação moderna, visto que o dinheiro assume papel fundamental para a manutenção do grupo. Além disso, o próprio festejo junino de Caruaru tem tomado dimensão mais mercadológica que popular.

Neste sentido, entendemos como uma resposta a este hibridismo as tentativas de fazer as bandas de pífanos tocarem em eventos e shows que não necessariamente estejam ligados a festejos religiosos ou populares, para que eles possam ter mais apresentações ao longo do ano, mantendo sua subsistência. A manutenção das bandas de pífano no próprio São João de Caruaru, mesmo tendo essa festa uma conotação mais mercadológica, também é entendida como uma resposta ao hibridismo. Isso porque essas bandas têm que lidar com essa nova conotação moderna do evento, mas não de forma pacífica, uma vez que eles estão frequentemente tentando garantir seu lugar e reconhecimento no evento, diante das bandas que promovem os grandes shows.

No caso do bumba-meu-boi estudado, cada personagem, assumido por um membro da família do Sr. RG, desenvolve uma atividade e existe uma história para cada personagem que os orienta na performance. O boi, o Mateus e a Catirina são personagens centrais, e a história deles envolve a morte do boi pelo Mateus a pedido de Catirina e a ressurreição do animal (Notas de campo). Todas as apresentações revivem essa história por meio de uma linguagem essencialmente lúdica, marcada pela musicalidade e pela dança, uma vez que os atores fazem sua performance dançando ao som do batuque e acompanhando as loas (músicas criadas pelo grupo).

Assim como no caso das apresentações das bandas de pífano, percebemos no discurso dos integrantes do bumba-meu-boi (Sr. RG, entrevista, 20 de fevereiro de 2016) que existe uma necessidade de sobrevivência financeira do grupo ao longo de todo o ano, apesar de ele só realizar apresentações esporádicas, algumas delas não pagas. Neste sentido, também é possível perceber 
certo esforço em inserir as apresentações do bumba-meu-boi em vários eventos da cidade, além dos populares, como foi possível observar na inserção do bumba-meu-boi estudado no palco principal do São João de Caruaru, no ano de 2015, evento este que possui orientação moderna, uma vez que envolve interesses políticos e de Mercado.

\subsection{Prática do Cortejo do Bumba-Meu-Boi}

A prática do cortejo possui uma diferença fundamental da prática de apresentação em locais fixos: o cortejo segue pelas ruas e bairros de Caruaru arrecadando dinheiro por onde passa e fazendo pequenas apresentações para quem contribui (Nota de campo, 08 de fevereiro de 2016). Essa é uma prática antiga, feita em todos os carnavais e vista como uma brincadeira, mas uma brincadeira árdua e trabalhosa, como pudemos constatar durante as sete horas de cortejo que acompanhamos na cidade de Caruaru e as cinco horas de preparação e cortejo que acompanhamos na cidade de Olinda.

A história e personagens são basicamente os mesmos das apresentações, bem como o ritmo do maracatu, a dança, as roupas. Entretanto, os cortejos são muito mais longos e envolvem mais atividades como o deslocamento para os diferentes bairros, a arrecadação de dinheiro, a venda de blusas e DVDs, paradas para descanso e alimentação, reverências e uma tradição singular do bumba-meu-boi estudado, que é receber a bênção de um representante do candomblé.

As reverências são feitas a pessoas e entidades importantes para o bumba-meu-boi. No cortejo que acompanhamos na cidade de Caruaru, observamos uma reverência feita a um senhor representante do candomblé, que cedeu sua casa para que os integrantes do cortejo pudessem descansar e almoçar. Na reverência, cada personagem do bumba-meu-boi se curva diante da pessoa ou entidade em respeito a ela.

Além da reverência, o boi recebe bênção desse representante do candomblé em nome dos orixás, uma vez por ano. Para receber esta bênção, os estandartes são colocados dentro de uma sala com várias imagens de santos e com o representante do candomblé, que lhes abençoa com palavras inaudíveis. Sr. RG (conversa informal, 08 de fevereiro de 2016) diz que esta é uma tradição antiga, que acontece todos os anos e que ele "não é contra nem a favor, mas respeita a crença de M. [ representante do candomblé], pois as suas culturas conversam". A persistência dessa atividade dentro da prática do cortejo mostra a prevalência de um ethos com orientação tradicional, uma vez que existe uma preocupação em salvaguardar costumes mesmo que o atual representante do boi não acredite necessariamente nela, diferentemente do seu pai, o Mestre G, que coordenou o bumbameu-boi até seu falecimento.

No cortejo ocorrido na cidade de Olinda, a Sra. DL (conversa informal, 10 de fevereiro de 2016) nos informou que o grupo recebeu doações de roupas e adereços de uma pessoa do sudeste do país, que brincava em escolas de samba e, ao observar estas roupas e adereços sendo inseridos na brincadeira do bumba-meu-boi, foi possível constatar certa plasticidade dessa manifestação da cultura popular, uma vez que ela consegue inserir e adaptar novos elementos, dando-lhes sentido dentro do conjunto de significados da prática do cortejo. Isso pode ser interpretado como uma intertextualidade, uma vez que os discursos de um grupo (as roupas de escolas de samba) são inseridos em outro grupo (no bumba-meu-boi). Também pode ser interpretado como um verdadeiro hibridismo dessa prática, uma vez que os adereços das escolas de samba, incrementados e modernos, misturam-se com as fantasias tradicionais do bumba-meu-boi.

O ethos predominante nessa prática possui orientação tradicional, uma vez que existe a prevalência de costumes familiares, além de ser possível observar ações orientadas pelas emoções. A fala dos familiares sobre a realização da brincadeira, como foi possível constatar na fala do Sr. RG (entrevista, 20 de fevereiro de 2016), é, muitas vezes, constituída por termos como amor e paixão pelo que se faz. Isso se mostra evidente quando se percebe que o discurso elaborado referente ao contexto do trabalho é semelhante, se não o mesmo, do discurso elaborado pelos agentes da família do Mestre G. para o contexto familiar e privado.

Percebemos ainda que a principal resposta ao hibridismo observado nesta prática é a manutenção do cortejo em seu formato essencial, com os mesmos significados, mesmo que as crenças e roupas atuais sejam diferentes daquelas predominantes no início do grupo. 


\subsection{Prática de Preparação para as Apresentações e Cortejos}

Essa prática dura o ano inteiro e se intensifica quando as apresentações se aproximam, principalmente no caso do bumba-meu-boi estudado, que envolve muitas pessoas e é realizado pela família do Mestre G., já falecido, pai de Sr. RG. A confecção das fantasias é uma das principais atividades dessa prática, pensada desde o início do ano, quando a Sra. DL começa a reservar dinheiro para comprar alguns metros de tecido, bem como tinta, lantejoula, miçangas, linha etc. Ela e suas filhas são as principais responsáveis por essa atividade, o que exige habilidade em costura, apesar de nenhuma delas ter formação profissional para isso. É a Sra. DL quem define a maior parte das fantasias e roupas a serem feitas, como diz Sr. RG (entrevista, 20 de fevereiro de 2016): “muitas roupas minha mãe ainda tem aquela prática antiga que o que ela faz a gente tem que aceitar porque é o que ela gosta de fazer, é o que ela faz, e se não obedecer ela quebra no cacete, é o jeito dela [ risos]".

Apesar de ter inserido a confecção das roupas como uma atividade dentro da prática de preparação para as apresentações e cortejos, ela pode também ser entendida como uma prática própria, por envolver uma série de atividades, tais como o corte do tecido, que é feito tomando como base o modelo da roupa que se pretende construir e o tamanho da pessoa que vai vestir; o alinhavado, que consiste em unir os pedaços cortados através de pontos grandes, para posicioná-los na forma como serão costurados; a própria costura; e o bordado, que se refere a inserção de adereços como miçangas e lantejoulas (Sra. ZZ e Sra. DL, entrevista, 27 de fevereiro de 2016).

A Sra. DL costurava a mão quando a família assumiu o bumba-meu-boi estudado e, com o tempo, passou a utilizar a máquina de costura. Primeiro a de pé, depois as máquinas caseiras, hoje a industrial. Esta, para Sr. RG (entrevista, 20 de fevereiro de 2016), adianta o processo. Apesar da necessidade de fazer muitas fantasias, existe apenas 1 máquina para todo o grupo, máquina esta que quebrou depois do trabalho no carnaval 2016 (Sra. ZZ e Sra. DL, entrevista, 27 de fevereiro de 2016).

Outras atividades compõem essa prática, no caso do bumba-meu-boi, como limpar a sede, vestir as fantasias, construir os estandartes, pintar o corpo etc. No caso da banda de pífano, a preparação se dá mais no sentido de vestir as roupas características (que acontece momentos antes das apresentações), ensaiar os instrumentos, afiná-los.

As roupas usadas pelos integrantes das bandas de pífano podem variar, principalmente ao considerar as roupas usadas pelas diferentes bandas ao longo da história. Porém, no caso das bandas atuais caruaruenses, é possível observar certa repetição: blusas de botão estampadas com manga comprida e chapéu de couro. O Sr. ZG (entrevista, 20 de fevereiro de 2016) explicou que estas são roupas típicas de cortadores de cana que trabalham expostos ao sol, uma vez que a camisa os protege dos raios solares, além de ser feita de tecido que seca com facilidade. O chapéu, de acordo com ele, serve como 'cuia' para tomar água, além de proteger o rosto do sol, como usava Lampião.

Foi possível observar, principalmente nas falas dos entrevistados, sobre as roupas e fantasias elaboradas, um ethos cuja orientação é predominantemente tradicional, por manter costumes nos modos de fazer as roupas e fantasias necessárias às apresentações. No caso do bumba-meu-boi esses costumes associam-se principalmente ao trabalho da Sra. DL na elaboração das fantasias.

O principal hibridismo identificado foi a necessidade de agilizar o processo de costura das roupas do bumba-meu-boi. A resposta identificada a este hibridismo diz respeito à utilização de máquina de costura industrial pela Sra. DL e suas filhas (que quebrou após a confecção das fantasias para o carnaval de 2016).

\subsection{Prática de Construção dos Instrumentos}

A construção dos instrumentos constitui uma prática importante por ser, algumas vezes, uma fonte de renda dos fazedores e artistas da cultura popular que os produzem e os vendem a terceiros. Dessa forma, a construção desses instrumentos acaba constituindo uma possibilidade de profissionalização para pessoas que buscam ocupação, como Sr. AP deixa claro nas aulas de pífano que acontecem na sede da banda de pífano, com crianças da cidade (Notas de Campo, 20 de fevereiro de 2016).

Nas falas do Sr. AP e dos Srs. ZG, MA e MS, componentes da banda de pífanos, foi possível identificar que os instrumentos construídos pelos mestres têm maior valor, avaliado tanto em termos da construção artesanal e única de cada mestre, em função da maior durabilidade do instrumento 
construído artesanalmente, além disso, permite a perpetuação dessa manifestação cultural entre gerações ("de pai para filho") e a construção e continuação da história do folguedo.

Os instrumentos de percussão (zabumba, contrassurdo e caixa de guerra) possuem quatro partes principais: o aro, o corpo, superfície e a corda. Quando eles são feitos artesanalmente, na construção do aro são utilizadas madeiras de árvore de juá, de aroeira ou de baraúna, árvores facilmente encontradas na região do agreste pernambucano. As madeiras da aroeira e da baraúna, conhecidas também como pau-ferro, servem ainda para a construção do corpo dos instrumentos de percussão por serem madeiras fortes, que suportam altos pesos sem se danificarem. Na superfície do instrumento (e também embaixo, no caso da zabumba) é utilizada pele de bode que passa por um processo no qual se usa cal para a retirada do pelo do animal. Após esse processo, a pele fica dura e é necessário passar um tempo de molho na água para que ela amoleça e seja fixada ao instrumento. As cordas que amarram e afinam o instrumento, por sua vez, são feitas com cipó (Sr. AP, entrevista 13 de fevereiro de 2016).

O pífano é feito com madeira de taboca ou taquara, que são variações do bambu bastante encontradas na região do agreste pernambucano anos atrás, mas em extinção atualmente. Ferros aquecidos são utilizados para fazer os sete furos na flauta - um furo feito para soprar e mais seis para dedilhar. A distância dos furos dos dedos depende da escala utilizada por cada pifeiro, o que é algo bastante pessoal, a depender da forma que cada um toca (Sr. AP, entrevista 13 de fevereiro de 2016).

No caso do bumba-meu-boi, apenas a alfaia é construída pelo próprio grupo, sendo o responsável por essa atividade um dos netos do Mestre G., que conta com o auxílio de outro neto e de um dos filhos do Mestre. O material comprado para a fabricação dessas alfaias, atualmente, é um compensado tipo laminado, prego, cola, pele de couro de bode já curtida e a corda, que pode ser de pé de caruá ou corda de nylon, esta última sendo mais prática para afinar o instrumento (Sr. RG, entrevista, 20 de fevereiro de 2016).

A extinção ambiental, um fenômeno atual e moderno, bem como as leis ambientais que impedem a derrubada de árvores, têm influenciado a fabricação desses instrumentos (Sr. AP, entrevista 13 de fevereiro de 2016; Sr. ZG, entrevista, 20 de fevereiro de 2016). O material do qual é feito o pífano está cada vez mais escasso, como dito anteriormente, e a derrubada de árvores como a baraúna ou a aroeira pode infringir crime ambiental. Diante desse elemento moderno, que é reconhecido pelos próprios mestres, as principais saídas são utilizar materiais sintéticos como o aglomerado, o compensado, couro sintético, cordas comuns reutilizáveis e cano PVC para fazer o pífano.

A utilização desses materiais, que produzem instrumentos menos duráveis, é uma resposta ao principal hibridismo observado nesta prática, nomeadamente a valorização dos instrumentos feitos artesanalmente e as demandas ambientais atuais referentes a extinção das espécies. Esta questão ficou clara nas falas nos integrantes da banda de pífano, que sempre a enfatizavam. Uma frase que representa bem a compreensão desse hibridismo por partes dos artistas foi dita pelo Sr. AP (entrevista, 13 de fevereiro de 2016): “[ com a utilização de materiais sintéticos] ganha-se na questão ambiental, mas perde-se no valor histórico".

Outra resposta encontrada é a própria compra dos instrumentos pelos grupos, ou seja, a não realização da prática de construção do instrumento. Uma vez que eles não podem produzi-lo em função da falta de recursos ambientais para fazê-lo, eles compram instrumentos já feitos, geralmente feitos com os materiais sintéticos mencionados anteriormente, que não possuem tanta durabilidade quanto os naturais.

\subsection{Prática das Aulas de Pífano}

É nesta prática que ocorre a transmissão de saberes relativos à atividade de tocar o pífano e os outros instrumentos que constituem a banda. Os mestres Sr. AP, Sr. ZG, Sr. MA e Sr. MS ensinam, de forma oral, como tocar os instrumentos, guiando seus alunos apenas pelo som que o instrumento emite. Os alunos e alunas aprendem através do contato com os instrumentos e da repetição contínua dos mesmos sons, de forma que possam memorizá-los, assim como fizeram os mestres. Identificamos como principais atividades nessa prática a preparação dos instrumentos (como trocar as cordas e afiná-los), o desmonte dos instrumentos e sua montagem, o apoio às crianças que usam os instrumentos e o registro fotográfico.

É possível dizer que esta prática está permeada por outras já discutidas até o momento. Na atividade referente à preparação dos instrumentos, observa-se que a afinação está também na 
prática de preparação para as apresentações. Na atividade de montagem e desmontagem dos instrumentos, pode-se observar elementos relativos à construção dos instrumentos, principalmente a questão dos significados compartilhados, uma vez que as crianças começam a entender o valor de construir o próprio instrumento. $\mathrm{Na}$ atividade referente ao apoio às crianças, os mestres transmitem o conhecimento que possuem sobre o fazer musical, que serve de base para a prática das apresentações, no caso da banda de pífanos.

É possível dizer que a prática da aula de pífano, por manter costumes como a aprendizagem via oralidade e a valorização da confecção artesanal dos instrumentos, possui ethos com orientação tradicional. Entretanto, elementos modernos estão presentes, como o uso de tecnologias que permitem registros fotográficos e em vídeo.

Outro elemento moderno que não está tão claramente presente, mas que surge a partir da reflexão sobre esta prática, é a profissionalização. Por mais que os discursos proferidos pelos mestres-professores nessa prática deixem claro que o objetivo das aulas é manter viva a tradição do pífano, é possível identificar uma preocupação com a profissionalização dessas crianças, uma vez que Ihes é apresentada a possibilidade de construir uma carreira profissional como tocador de pífano, ou de conseguir remuneração por construir e vender instrumentos. O próprio fato de as aulas acontecerem através de incentivo da Fundação de Cultura do Município e de maneira sistemática por meio de encontros semanais, esse elemento moderno é reforçado, assim como a profissionalização dos alunos, uma vez que normatiza e institucionaliza a prática.

Neste sentido, o hibridismo observado nessa prática diz respeito principalmente ao fato de as aulas terem como objetivo principal ensinar as crianças a tocarem nas bandas de pífano, preservando os costumes associados a essa habilidade, mas também terem um objetivo latente de profissionalizar essas crianças, para que elas possam ter uma fonte de renda através do trabalho com o pífano. Vemos como principal resposta a esse hibridismo a capacidade de a banda de pífano atrelar estes dois objetivos em aulas semanais e sistemáticas nas quais as crianças aprendem, por meio da oralidade com os mestres, um fazer cultural que pode lhes garantir um posicionamento no mercado de trabalho no futuro.

\section{Discussão}

Como observado na análise realizada acima, várias são as práticas de trabalho possíveis para as organizações de cultura popular, cada qual com atividades, linguagens, significados específicos. Para cada prática, hibridismos foram identificados, tomando como parâmetro para a noção de hibridismos os estudos de Canclini $(1995 ;$ 2013) que analisa a cultura popular no México, percebendo que esta é composta por processos híbridos que reúnem práticas singulares, que existiam separadamente. No caso dessa pesquisa, consideramos como processos híbridos aqueles que reúnem elementos modernos e tradicionais. No contexto das organizações culturais estudadas, esse hibridismo ocorre principalmente em função de as práticas das apresentações, dos cortejos e dos preparativos para estes acontecimentos possuírem ethos cuja orientação é essencialmente tradicional (por predominarem costumes e crenças familiares antigos). Entretanto, recursos financeiros se fazem necessários para a manutenção dessas práticas (o que já evidencia orientação moderna, visto que o elemento financeiro se torna crucial para a sobrevivência do grupo) e, para isso, projetos culturais, bem como ofícios, leis etc., passam a ser desenvolvidos visando fins específicos, caracterizando uma ação racional com base em fins (Weber, 2014). Questões modernas como o desmatamento e a necessidade de acelerar processo de costura também se fazem presentes nas práticas, convivendo com os elementos tradicionais expostos.

Para além da compreensão dos hibridismos, Greenwood, Raynard, Kodeih, Micelotta e Lounsbury (2011) apontam para a importância de entender também a forma como as organizações respondem a esses conflitos entre lógicas, uma vez que os sujeitos sociais em suas práticas de trabalho possuem agência. Deste modo, as várias respostas observadas dadas aos hibridismos identificados foram: A ação dos conselheiros municipais de cultura e outros líderes de grupos da cultura popular, como Sr. AP e Sr. RG, que caminham entre vários ethos; a existência de formas de fazer projetos marcadas pela informalidade, conforme discutido por Holanda (2011); as parcerias dos artistas da cultura popular com os produtores culturais, bem como o crescimento desses profissionais na cultura popular, conforme aponta Santos (2013); a busca por auxílio contábil e jurídico; a inserção das bandas de pífanos em eventos alternativos aos religiosos e populares; a própria manutenção da banda de pífanos no São João de Caruaru e a inserção do bumba-meu-boi no palco desse mesmo evento no ano de 2015; a manutenção do cortejo do bumba-meu-boi mesmo com crenças distintas daquelas presentes em sua origem, ou roupas diferentes, não elaboradas pelo grupo; utilização de máquinas industriais na produção das roupas para adiantar o processo de 
costura; a utilização de materiais sintéticos como o aglomerado, o compensado, couro sintético, cordas comuns reutilizáveis, cano PVC para a construção de instrumentos; a não construção de instrumentos, optando-se pela compra destes a terceiros.

Fazendo analogia à noção de "condição dupla" na qual o feirante do Agreste pernambucano se encontra (Sá, 2013), identificamos que o artista ou fazedor de cultura popular vem de uma condição na qual prevalecem modelos informais de trabalho e de aprendizagem (uma vez que eles encaram o trabalho como uma brincadeira, aprendem por meio da oralidade, não possuem normas racionais de organização do trabalho etc.), mas prevalecem práticas as quais predominam elementos modernos e formais (como a prática de elaboração de projetos, por exemplo).

Essa condição dupla não se dá somente por meio de convívio harmonioso entre elementos modernos e tradicionais. Por vezes, existe um conflito ou um convívio não equilibrado, no qual uma configuração se sobrepõe a outra (geralmente a moderna sobrepondo a tradicional). Assim, é possível observar que a exigência por escrever projetos nos moldes burocráticos e formais tem se sobreposto à realização de solicitação informal de recursos para desenvolver atividades, por exemplo.

Assim como discutido por Véras de Oliveira (2013), sobre as organizações informais existentes no Agreste pernambucano estarem passando por modernizações com a pressão por profissionalização, também observamos que essa busca por profissionalização tem sido uma constante no trabalho com cultura popular, conforme observado na prática das aulas de pífano. Nesse caso, é possível observar aquilo que Almeida e Pais (2012) denominam "profissionalização da criatividade", ou seja, a atribuição de uma envergadura profissional, característica das organizações empresariais, para atividades criativas [ e culturais].

Autores como Gameiro et al. (2003), Madeiro e Carvalho (2003), Santos e Costa (2015) também observam forte pressão de modernização racional-técnica em outros grupos de cultura popular. Tais pressões por modernização se dão tanto no sentido de massificar a produção proveniente do trabalho com cultura popular (como no caso do artesanato), quanto no sentido de profissionalizar e assalariar estes trabalhadores. Estas pressões, entretanto, são marcadas por um jogo relacional, no qual os trabalhadores envolvidos possuem estratégias de ação e lutam com os recursos de poder que possuem, seja no sentido de resistir, seja no sentido de reconverter patrimônios para reinseri-los em novas condições de produção e mercado (Canclini, 2013).

No caso da banda de pífano e do bumba-meu-boi estudados, é possível observar tanto a resistência a discursos extremamente técnicos, como visto nas reuniões dos fóruns e conselhos, uma vez que eles buscam manter valores tradicionais, como a reconversão de patrimônios para sua reinserção no mercado, que é possível constatar na prática de construção de instrumentos para subsistência. Neste sentido, parece ocorrer aquilo que Farias (2005, p. 677) denomina de "remanejamento de estilos tradicionais", que "passam a constar do panorama do atual, compondo as problematizações [à modernidade] que ganham relevância nas práticas e sentimentos".

A partir da análise realizada acima, percebemos que os elementos modernos identificados são valorizados pelos artistas e fazedores da cultura popular, à medida que permitem a manutenção dessa cultura. Em outras palavras, é por saber que as iniciativas modernas podem ajudar a manter a tradição da cultura popular que os agentes que constituem essa cultura legitimam tais iniciativas. Essa legitimação se dá, por exemplo, na valorização que esses agentes dão à política de editais (observação no I Fórum Setorial de Povos Tradicionais e na Capacitação Regionalizada do Funcultura 2016) como uma forma de democratização de recursos para o campo da cultura, ou na ação orientada a profissionalização nas aulas de pífano. Ou seja, o elemento moderno é visto como valoroso e importante para a cultura popular em função do elemento tradicional que mantém vivo.

Dessa forma, é possível afirmar que os elementos tradicionais que constituem as práticas de trabalho da cultura popular no Agreste pernambucano são a base dos elementos modernos, servindo como uma espécie de "liga" para o convívio com estes últimos. Assim, os elementos modernos existentes nesse contexto existem em função dos elementos tradicionais, e os elementos tradicionais, para não se extinguirem, se relacionam de forma interdependente com os elementos modernos.

Essa constatação reforça a noção do hibridismo entre elementos modernos e tradicionais levantada na discussão teórica desse artigo, ou seja, a modernização acontece de forma particular no Agreste pernambucano, sobretudo no trabalho da cultura popular. Isso porque se, por um lado, existe a importância atribuída à tradição e costumes que mantém a característica fundamental dos grupos estudados, por outro lado eles precisam garantir sua manutenção e conquistar novos 
espaços modernos. Por este motivo, desenvolvem atividades que atendem a um ethos moderno, guiado por ações sociais baseadas em fins.

Apesar disso, nos parece evidente que a orientação para o lucro econômico, desenvolvida com a oferta de serviços culturais, como observado por Farias (2005) ao analisar diferentes festas populares no Brasil (como carnaval, São João etc.) - ainda não se concretiza para as organizações estudadas. Os agentes que compõem estas e outras organizações culturais no contexto estudado ainda buscam formas de reconhecimento e de sobrevivência para manterem o desenvolvimento das suas práticas lúdicas (utilizando os termos de Farias (2005)). Neste sentido, percebemos que o ethos moderno existente nas práticas observadas ainda não garantem a plena vivência de uma lógica moderna e capitalista para as organizações estudadas, tendo em vista que uma indústria do entretenimento ainda não se estabeleceu efetivamente para as organizações de bumba-meu-boi e de pífanos na cidade de Caruaru-PE.

Algumas práticas analisadas carregam um “potencial” para articular-se à lógica mercadológica moderna, como por exemplo, a prática de apresentação em locais fixos, visto que tais apresentações tornam tangíveis[1], em certa medida, as tradições caruaruenses, além de permitirem uma aproximação com consumidores (que às vezes pagam para assistirem as apresentações em bares, casas de show etc.), exaltando a tradição e identidade da cidade e região, como propuseram Dalmoro e Nique (2017), ao estudarem a mercantilização das tradições gaúchas. Entretanto, tais "práticas de mercado", como mencionam os autores, acontecem de forma não estruturada no contexto da cultura popular caruaruense, e os artistas, mestres e fazedores que desenvolvem essa cultura, de modo geral, não usufruem dos benefícios, sobretudo econômicos, de estarem inseridos numa indústria do entretenimento. Isso se evidencia nas observações realizadas pelos autores deste trabalho, que levam a crer que as pessoas que desenvolvem a cultura popular na cidade constituem parcela humilde da população, moradores de bairros periféricos da cidade, que por vezes não tiveram oportunidade de cursar o ensino formal.

Por outro lado, é possível observar uma retomada da tradição por pessoas mais jovens na região, como pode ser observado na prática de aulas de pífanos, nas quais um público jovem se faz presente para aprender a tocar os instrumentos. Este movimento se aproxima daquele observado por Mira (2014), quando esta constata a recriação de grupos de maracatu na cidade de São Paulo, revivendo tradições antigas. Isso se dá, segundo a autora, em função da busca por uma experiência comunitária; da busca por reconstruir identidades e ancestralidades, resgatando autoestima e memória de classes estigmatizadas; e da busca por uma maior preservação ambiental relacionada a modos de vida tradicionais.

Entretanto, essa mediação da tradição que ocorre nas organizações de cultura popular em Caruaru ainda não se efetiva como uma mediação de classes, como Mira (2014) observou em sua pesquisa, tendo em vista que são as classes populares que continuam desenvolvendo a cultura popular na cidade e região, não alcançando ainda a classe média/ alta Agrestina. Isso pode ser um dos motivos para a falta de reconhecimento destacada pelos agentes culturais (Notas de campo, 17/12/2015; 19/01/2016), dado o papel das elites na legitimação das manifestações culturais, por meio do seu capital cultural.

Apresentadas estas questões e considerando a relevância em discutir o papel do mercado, como elemento moderno que se mescla cada vez mais às tradições das culturas populares, conforme evidenciado por Farias (2001; 2005) e Dalmoro e Nique (2017), cabe aqui uma reflexão acerca da própria lógica da indústria do entretenimento, ou da mercantilização das tradições. A questão que se julga fundamental para se pensar a cultura popular em qualquer localidade é: até que ponto é possível garantir que as camadas populares, que desenvolvem a cultura popular, dado o seu histórico de desfavorecimentos sociais em comparação às elites, sejam beneficiadas diretamente, caso se insiram na chamada "indústria do entretenimento-lazer", utilizando a nomenclatura de Farias $(2001 ; 2005)$ ?

Acreditamos ser importante não excluir as culturas populares de movimentos modernos e mercadológicos, uma vez que é possível manter e fortalecer tradições utilizando tais elementos, como os próprios agentes da cultura popular em Caruaru já o fazem. Esse fortalecimento das tradições, utilizando os meios modernos se dá, por exemplo, na prática de participação da sociedade civil na elaboração de políticas culturais, apresentado anteriormente. Entretanto, é importante levar em consideração que é fundamental que os agentes culturais sejam protagonistas na elaboração das práticas de mercado que Ihes permitam manter o desenvolvimento de suas práticas culturais, garantindo sustentabilidade para as organizações das quais fazem parte e valorização dos saberes populares, fundamentais para a existência das tradições e para a transmissão entre diferentes gerações. 
Nota-se, portanto, o caráter conflituoso das práticas híbridas existentes nas organizações de cultura popular no agreste pernambucano. Tais práticas, longe de relacionarem harmoniosamente os elementos e forças modernos e tradicionais, carregam consigo uma constante luta de forças, ora prevalecendo aspectos modernos e mercadológicos, ora prevalecendo as tradições e,às vezes, mesclando tais aspectos em respostas estratégicas dadas pelos agentes em ação.

\section{Conclusões}

Neste artigo, buscamos compreender os hibridismos entre ethos moderno e tradicional e as respostas a eles existentes nas práticas de trabalho da cultura popular na realidade do Agreste pernambucano. Para tanto, investigamos duas organizações de cultura popular localizadas na cidade de Caruaru-PE: uma banda de pífanos e um grupo de bumba-meu-boi.

Por meio de observação participante, entrevistas semiestruturadas, conversas informais e análise com orientação etnometodológica, identificamos sete práticas de trabalho principais: a prática da participação da sociedade civil na construção de políticas públicas de cultura, a prática de elaboração de projetos culturais, a prática de apresentação em locais fixos, a prática do cortejo do Boi Tira Teima, a prática de preparação para as apresentações e os cortejos, a prática de construção dos instrumentos e a prática das aulas de pífano.

Constatamos que os elementos modernos que se fazem presentes nas práticas de trabalho da cultura popular se legitimam nas ações e discursos dos fazedores de cultura por sua capacidade de permitir que o tradicional se mantenha vivo. A exemplo disso, constatamos que a elaboração de projetos culturais, a interpretação de leis e editais públicos, a elaboração de ofícios, entre outros, estão próximos ao conceito de ação racional com base em fins, mas ao mesmo tempo permitem a manutenção de costumes e tradições, das histórias e da brincadeira em si, tais como as apresentações das bandas de pífano, a construção de instrumentos, a realização de cortejos pela cidade em época de carnaval etc.

Importante destacar, a título de conclusões, que as práticas, os hibridismos e as respostas dadas a eles, identificadas durante nossas inserções em campo, não esgotam as possibilidades no trabalho em organizações da cultura popular. O tipo de pesquisa aqui empreendido depende sobretudo [2]do que o campo diz aos pesquisadores num determinado tempo e espaço, a partir de uma configuração específica da realidade estudada. Com isso, queremos dizer que o que o campo nos revelou neste período pode ser revelado de forma diferente em outro momento, uma vez que a dinâmica do trabalho com cultura popular muda continuamente.

Expomos como principais limitações da pesquisa, em primeiro lugar, a falta de oportunidade de acompanhar atividades/práticas que existem no trabalho com cultura popular no Agreste, mas que não aconteceram entre dezembro de 2015 e março de 2016. Foi o caso, principalmente, das rodas de diálogo com mestres da cultura popular e das negociações diretas entre artistas e representantes do poder público ou de empresas. Em relação à primeira, soubemos da sua ocorrência já nas últimas idas a campo, por meio de comentário na reunião do Conselho Municipal de Cultura. Em relação à segunda, essas negociações aconteceram de forma bastante reservada e não aberta ao público, o que impossibilitou melhores esclarecimentos sobre esta prática.

A segunda limitação diz respeito à impossibilidade, dentro do período definido para a confecção desta pesquisa, de investigar a realidade de outros grupos de cultura popular, o que, acreditamos, possibilitaria uma visão mais ampla e rica das relações de trabalho da cultura popular no Agreste pernambucano. Dito isto, umas das sugestões para estudos futuros é a investigação de outras organizações de cultura popular, tanto no Agreste quanto em outras regiões do país, a fim de tecer comparativos sobre suas realidades.

Sugerimos também que a estrutura de referência teórica proposta nesta pesquisa possa ser utilizada para entender as relações instituídas em outros trabalhos, que não o da cultura popular, e em outros contextos, com formações sociais, econômicas e culturais diferentes do Agreste pernambucano ou do Nordeste brasileiro.

Por fim, concluímos que uma das principais contribuições desta pesquisa para o campo de estudos sobre práticas é sua proposta multi e interdisciplinar, que agrega os Estudos Baseados em Prática à noção de ethos e ação social, visando compreender em que medida uma mesma prática pode ser entendida como moderna e tradicional ao mesmo tempo, constituindo verdadeira prática híbrida. Aplicar esta proposta de interpretação à realidade de organizações de cultura popular nos parece um primeiro e importante começo para o estudo das complexas organizações não formais, pouco estudadas pelo mainstream do campo da administração. 
Outra contribuição visualizada é o estudo de organizações periféricas ao mainstream em uma realidade também periférica, nomeadamente, o Agreste de Pernambuco. Acreditamos que as realidades periféricas possuem especificidades em função de sua formação sócio-histórica, que interfere diretamente nas práticas realizadas pelas organizações locais e que merece ser compreendida e posta em análise, para o desenvolvimento de ações diversas, seja de caráter acadêmico ou da administração pública, tendo sempre em vista a emancipação dos agentes que compõem tais contextos.

\section{Notas}

1. Agradecemos às recomendações dos avaliadores da RECADM, que contribuíram para a expansão e desenvolvimento do presente artigo.

\section{Referências}

Adamoglu de Oliveira, S., \& Montenegro, L. M. (2012). Etnometodologia: desvelando a alquimia da vivência cotidiana. Cadernos EBAPE.BR, 10(1), 129-145.

Albuquerque, D. M., Jr. (2011). A Invenção do Nordeste e Outras Artes (5a ed.) São Paulo: Cortez.

Alcadipani, R., Khan, F. R., Gantman, E. \& Nkomo, S. (2012). Southern voices in management and organization knowledge.Organization, 19(2), 131-143.

Almeida, M. I. M., \& Pais, J. M. (2012). Criatividade, Juventude e novos horizontes profissionais. Rio de Janeiro: Zahar.

Andrade, M. M. (2009). Introdução à Metodologia do Trabalho Científico (9a ed.). São Paulo: Atlas.

Angrosino, M. (2009). Etnografia e observação participante. Porto Alegre: Artmed.

Araújo, T. B. (2004). Northeast, Northeasts: what northeast? Latin American Perspectives, 31(2), 1641.

Bispo, M. (2013). Estudos Baseados em Prática: Conceitos, História e Perspectivas. Revista Interdisciplinar de Gestão Social, 2(1), p. 13-33.

Bispo, M. (2015). Methodological Reflections on Practice-Based Research in Organization Studies. Brazilian Administration Review, 12(3), 309-323.

Bispo, M. S., \& Godoy, A. S. (2014). Etnometodologia: uma proposta para pesquisa em estudos organizacionais. Revista de Administração da Unimep, 12(2), 108-135.

Blass, L. M. S. (2007). Desfile na avenida, trabalho na escola de samba: a dupla face do Carnaval. São Paulo: Annablume.

Bourdieu, P., Chamboredon, J., \& Passeron, J. (2007). Ofícios do sociólogo: metodologia da pesquisa na sociologia. Petrópolis: Vozes.

Canclini, N. G. (1995). As Culturas Populares no Capitalismo. São Paulo: Brasiliense.

Canclini, N. G. (2013). Culturas Híbridas: estratégias para entrar e sair da modernidade (4a ed.). São Paulo: Editora da Universidade de São Paulo.

Chaui, M. (1989). Conformismo e resistência: Aspectos da cultura popular no Brasil (4a ed.). São Paulo: Brasiliense.

Dalmoro, M.; Nique, W. M. (2017). Tradição mercantilizada: Construção de mercados baseados na tradição. Revista de Administração Contemporânea, 21(3), 327-346.

Dourado, D. C. P., Holanda, L. A., Silva, M. M. M., \& Bispo, D. A. (2009). Sobre o sentido do trabalho fora do enclave de mercado. Cadernos EBAPE.BR, 7(2), 350-367.

Farias, E. S. (2001). Festas populares e entretenimento-turismo no Brasil (Tese de Doutorado). Universidade Estadual de Campinas, Campinas, SP, Brasil.

Farias, E. S. (2005). Economia e cultura no circuito das festas populares brasileiras. Sociedade e Estado, 20(3), 647-688.

Figueiredo, M. D. (2016). Uma Agenda de Pesquisa para o Estudo das Práticas Culturais Tradicionais nos Estudos Organizacionais. Revista Interdisciplinar de Gestão Social, 5 (2), 33-49.

Fischer, E. (1987). A necessidade da arte. (9a ed.). São Paulo: Editora Guanabara. 
Gameiro, R., Menezes, M. F., \& Carvalho, C. A. (2003). Maracatu Pernambucano: Resistência e Adaptação na Era da Cultura Mundializada. In Carvalho, C. A. \& Vieira, M. M. F. Organizações, cultura e desenvolvimento local: A agenda de pesquisa do Observatório da Realidade Organizacional. Recife, EDUFEPE.

\section{Gil, A. C. (2008). Métodos e Técnicas de Pesquisa Social (6a ed.). São Paulo: Atlas.}

Greenwood, R., Raynard, M., Kodeih, F., Micelotta, E. R., \& Lounsbury, M. (2011). Institucional Complexity and Organizational Responses. The Academy of Management Annals, 5(1), 317-371.

Gubert, A., \& Kroeff, L. R. (2001). Versões sobre o trabalho na rua: significações na relação do retratista com a sua arte. Psicologia: ciência e profissão. 21(1), 84-93.

Helal, D. H. (2015). Mérito, Reprodução Social e Estratificação Social: apontamentos e contribuições para os estudos organizacionais. Organizações \& Sociedade, 22(73), 251-267.

Holanda, L. A. (2011). Resistência e apropriação de práticas do management no organizar de coletivos da cultura popular (Tese de Doutorado). Universidade Federal de Pernambuco, Recife, PE, Brasil.

Imas, J. M., \& Weston, A. (2012). From Harare to Rio de Janeiro: Kukiya-Favela organization of the excluded. Organization, 19(2), 205-227.

Laraia, R. B. (1986). Cultura: um conceito antropológico. Rio de Janeiro: Jorge Zahar.

Madeiro, G., \& Carvalho, C. (2003). Da origem pagã às micaretas. In Carvalho, C. \& Vieira, M. Organizações, Cultura e Desenvolvimento Local. Recife: EDUFEPE.

Maynard, D., \& Clayman, S. E. (1991). The diversity of ethnomethodology. Annual Review of Sociology, 17, 385-418.

Menger, P. M. (2005). Retrato do artista enquanto trabalhador: Metamorfoses do capitalismo. Lisboa: Roma Editora.

Merriam, S. B. (2009). Qualitative Research: a guide to design and interpretation. San Francisco: Jossey-Bass.

Mira, M. C. (2014). Metrópole, tradição e mediação cultural: reflexões a partir da experiência dos grupos recriadores de maracatu na cidade de São Paulo. Revista Mediações, 19(2), 185-204.

Nicolini, D. (2009). Zooming In and Out: Practices by Switching Theoretical Lenses and Trailing Connections. Organizations Studies, 12(30), 1391-1418.

Nicolini, D. (2013). Practice Theory, Work, \& Organization: an introduction. Oxford: Oxford University Press.

Nicolini, D., \& Monteiro, P. (2016). The Practice Approach: For a Praxeology of Organisational and Management Studies. In Tsoukas, H. \& Langley, A. (eds). The SAGE Handbook of Process Organization Studies.London: SAGE. Retrieved from http://www.researchgate.net/publication/282334669_The_Practice_Approach_For_a_Praxeology_of_Or ganisational_and_Management_Studies_\%282016\%29.

Reckwitz, A. (2002). Toward a theory of social practices: a development in culturalist theorizing. European Journal of Social Theory, 5(2), 243-263.

Romero, J. J. C. (1991). Etnometodologia: una explicación de la construcción social de la realidad. Revista Española de Investigaciones Sociológicas, 56, 83-114.

Rosa, A. R., \& Alcadipani, R. (2013). A terceira margem do rio dos estudos críticos sobre administração e organizações no Brasil: (Re)Pensando a crítica a partir do pós-colonialismo. Revista de Administração Mackenzie,14(6), Edição Especial, 185-215.

Sá, M. G. (2013). Feirantes: Possíveis Contribuições. In Sá, M. G., Helal, D. H., Ferraz, A., \& Silva, J. P. Trabalho: Questões no Brasil e no Agreste Pernambucano.Recife: Ed. Universitária da UFPE.

Sá, M. G. (2015). Os filhos das feiras e o campo de negócios do Agreste. (Tese de Doutorado). Universidade do Minho, Braga, Portugal.

Santos, E. C. (2013). O produtor da cultura popular de Pernambuco frente às transformações das políticas culturais em 2003: uma abordagem relacional e disposicional. (Dissertação de Mestrado). Universidade Federal de Pernambuco, Recife, Brasil. 
Santos, E. C., Costa, M. (2015). Reflexões Teóricas sobre o Regime de Acumulação Flexível e a Mercantilização da Cultura. In Anais do Encontro de Estudos Multidisciplinares em Cultura. Salvador, BA, Brasil, 11.

Schatzki, T. R. (2001). Introduction: practice theory. In Schatzki, T. R., Knorr Cetina, K., \& SAVIGNY, E. von (eds.). The Practice Turn in Contemporary Theory. New York: Routledge.

Serviço Brasileiro de Apoio às Micro e Pequenas Empresas. (2012). Estudo Econômico do Arranjo Produtivo Local de Confecções do Agreste Pernambucano, 2012. Relatório Final. Recife, Brasil.

Silva, A. S. (2015). A Liderança como Relação Social: Uma Proposta de Abordagem Interpretativa a Partir da Teoria da Ação Social e das Estruturas Típicas de Dominação Weberianas. (Tese de Doutorado). Pontifícia Universidade Católica de Minas Gerais, Belo Horizonte, Brasil.

Silva, L. H., Jr., Sobral, E. F. M., \& Santana, O. M. S. (2012). Notas sobre a infraestrutura social e econômica do Agreste pernambucano. Economia e Desenvolvimento, 11(1), 108-136.

Souza, J. (2000).A modernização seletiva: uma reinterpretação do dilema brasileiro. Brasília: Editora Universidade de Brasília.

Souza, C. L. C. (2011). Panis et ars: artistas e gestores nas indústrias criativas. (Tese de Doutorado). Pontíficia Universidade Católica, Rio de Janeiro, RJ, Brasil.

Véras de Oliveira, R. (2013). O Pólo de Confecções do Agreste de Pernambuco: elementos para uma visão panorâmica. In Véras de Oliveira, R. \& Santana, M. A. Trabalho em territórios produtivos reconfigurados no Brasil. João Pessoa: Editora da UFPB.

Weber, M. (2005). A Ética Protestante e o Espírito do Capitalismo. São Paulo: Martin Claret.

Weber, M. (2014). Economia e sociedade: fundamentos da sociologia compreensiva. (4a. ed.). Brasília: Editora Universidade de Brasília. 